PNNL-12008

Rev. 1

\title{
Relative Hazard and Risk Measure Calculation Methodology
}

\author{
R.D. Stenner \\ M.K. White \\ D.L. Strenge \\ R.L. Aaberg \\ W.B. Andrews
}

September 2000

Prepared for the

Center for Risk Excellence

U.S. Department of Energy

Chicago Operations Office

Prepared by the

Pacific Northwest National Laboratory

Under Contract DE-AC06-76RLO 1830 


\section{DISCLAIMER}

This report was prepared as an account of work sponsored by an agency of the United States Government. Neither the United States Government nor any agency thereof, nor Battelle Memorial Institute, nor any of their employees, makes any warranty, express or implied, or assumes any legal liability or responsibility for the accuracy, completeness, or usefulness of any information, apparatus, product, or process disclosed, or represents that its use would not infringe privately owned rights. Reference herein to any specific commercial product, process, or service by trade name, trademark, manufacturer, or otherwise does not necessarily constitute or imply its endorsement, recommendation, or favoring by the United States Government or any agency thereof, or Battelle Memorial Institute. The views and opinions of authors expressed herein do not necessarily state or reflect those of the United States Government or any agency thereof.

\section{PACIFIC NORTHWEST NATIONAL LABORATORY \\ operated by \\ BATTELLE \\ for the \\ UNITED STATES DEPARTMENT OF ENERGY \\ under Contract DE-AC06-76RL01830}

Printed in the United States of America

Available to DOE and DOE contractors from the

Office of Scientific and Technical Information,

P.O. Box 62, Oak Ridge, TN 37831-0062;

ph: (865) 576-8401

fax: $(865) 576-5728$

email: reports@adonis.osti.gov

Available to the public from the National Technical Information Service,

U.S. Department of Commerce, 5285 Port Royal Rd., Springfield, VA 22161

ph: (800) 553-6847

fax: (703) 605-6900

email: orders@ntis.fedworld.gov

online ordering: $\underline{\mathrm{http}: / / w w w . n t i s . g o v / o r d e r i n g . h t m}$

This document was printed on recycled paper.

$(8 / 00)$ 


\section{Acknowledgements}

A special acknowledgement and thanks go to Al Young and Mark Bollinger of the Department of Energy - Center for Risk Excellence (CRE), and the CRE Board, for identifying the need, through the development of the site risk profiles, for the methodology addressed by the document. They also provided funding and support for the application of this methodology to site-specific risk profiles, which helped to iteratively develop the methodology using real site cases.

The authors also wish to acknowledge and thank Mark Gilbertson and the Department of Energy - Office of Science and Risk Policy (DOE/EM-52) for the insight to fund and promote the development of this document.

A special thanks also goes to Virginia Kay of the Department of Energy - Savannah River Site (DOE/SRS) and the SRS Citizen's Advisory Board (CAB) for their insight and guidance associated with the development of the Risk Measure methodology addition to the document.

The authors also wish to acknowledge and thank Bruce Napier (PNNL) for providing peer review and excellent technical suggestions for improving the document. 


\section{Table of Content}

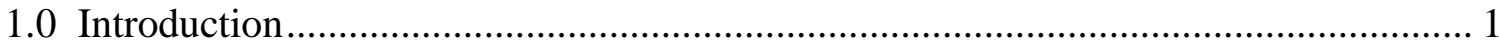

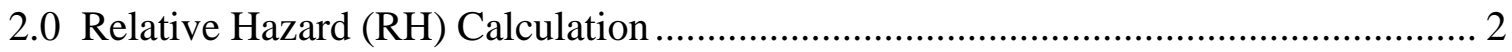

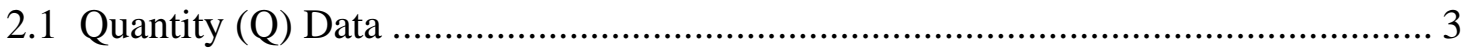

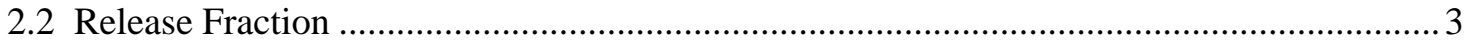

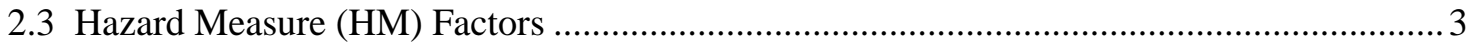

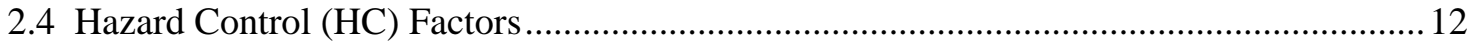

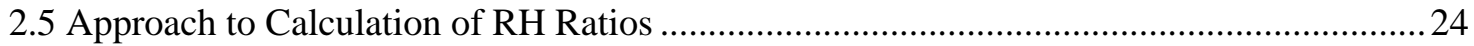

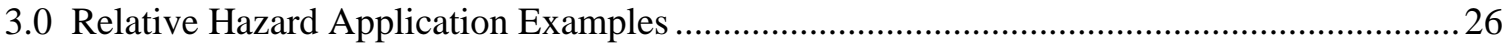

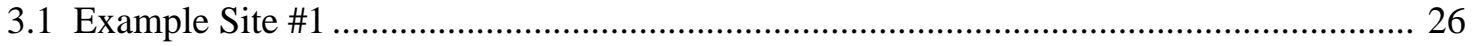

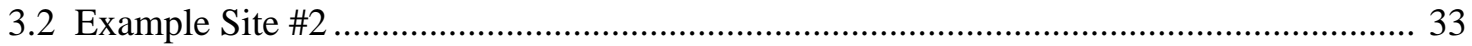

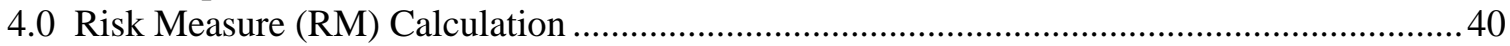

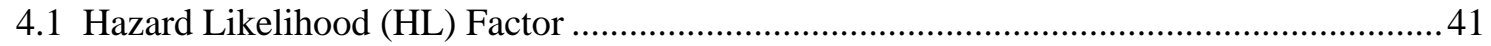

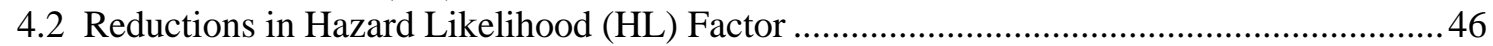

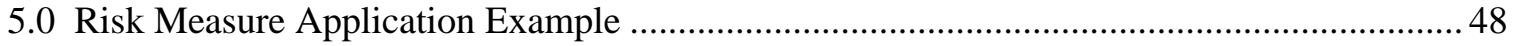

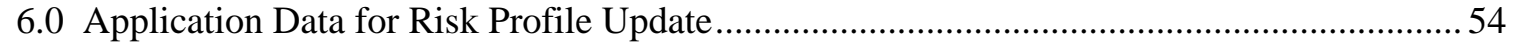

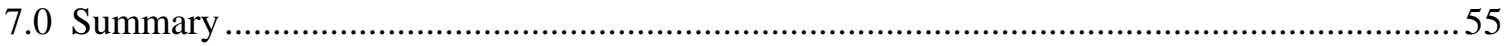

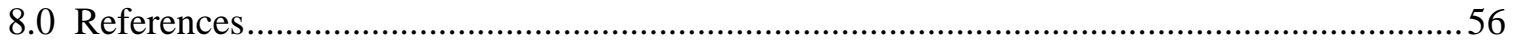




\section{Tables}

2.1 Air Exposure Pathway Groups for Radionuclides ............................................................... 6

2.2 Surface Water Pathway Groups for Radionuclides................................................................ 6

2.3 Partition Coefficients (Kd) and Derived GW Transfer Coefficients ...................................... 7

2.4 GW-to-Surface Water Exposure Pathway Groups for Radionuclides .................................... 8

2.5 Fire/Explosion Exposure Pathway Groups for Radionuclides ........................................... 8

2.6 Direct Contact Exposure Pathway Groups for Radionuclides ...............................................9

2.7 Hazard Measures for Chemicals Based on Reportable Quantities......................................... 10

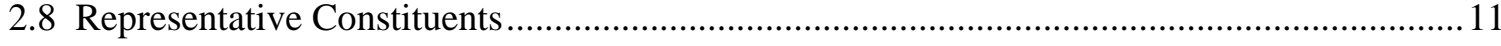

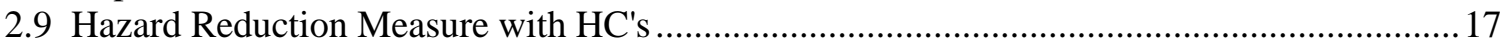

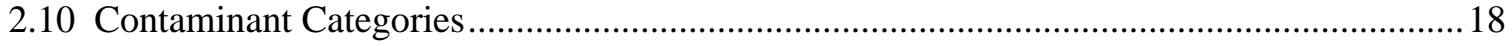

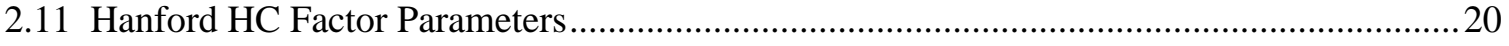

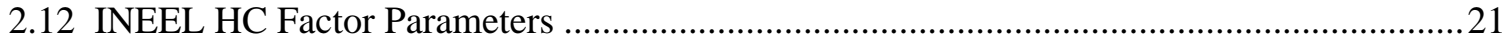

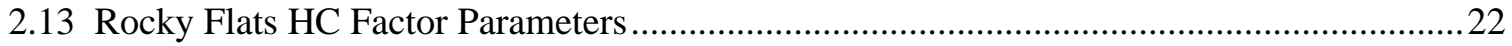

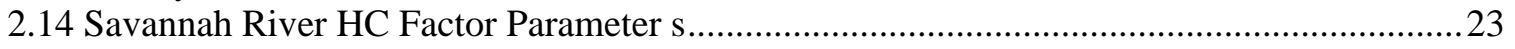

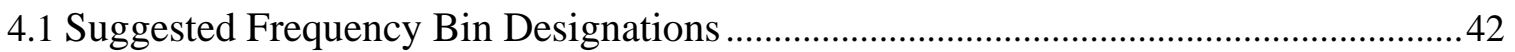

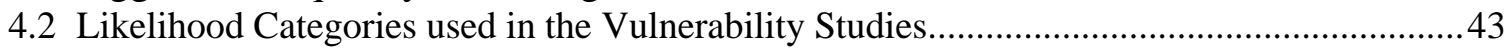

4.3 Likelihood Summary for Plutonium Vulnerability Study............................................ 44

4.4 Likelihood Summary for Highly-Enriched Uranium Vulnerability Study ...................45

4.5 Suggested Ranges in Likelihood Reductions.......................................................................4

5.1 Parameter Values for the Two SRS Vulnerabilities ............................................................ 49 


\subsection{Introduction}

In February 1997, the Center for Risk Excellence (CRE) was created and charged as a technical, field-based partner to the Office of Science and Risk Policy (EM-52). One of the initial charges to the CRE is to assist the sites in the development of "site risk profiles." These profiles are to be relatively short summaries (periodically updated) that present a broad perspective on the major risk related challenges that face the respective site. The risk profiles are intended to serve as a high-level communication tool for interested internal and external parties to enhance the understanding of these risk-related challenges. The risk profiles for each site have been designed to qualitatively present the following information: 1) a brief overview of the site, 2) a brief discussion on the historical mission of the site, 3) a quote from the site manager indicating the site's commitment to risk management, 2) a listing of the site's top risk-related challenges, 3) a brief discussion and detailed table presenting the site's current risk picture, 4) a brief discussion and detailed table presenting the site's future risk reduction picture, and 5) graphic illustrations of the projected management of the relative hazards at the site. During fiscal year 1998, risk profiles for the Richland Operations Office (DOE, 1998a), Nevada Operations Office (DOE, 1998b), Rocky Flats Field Office (DOE, 1998c), Savannah River Operations Office (DOE, 1998d), and Albuquerque Operations Office (DOE, 1998e) were developed, which utilized the methodology discussed in this report.

The graphic illustrations were included to provide the reader of the risk profiles with a high-level mental picture to associate with all the qualitative information presented in the risk profile. Inclusion of these graphic illustrations presented the CRE with the challenge of how to fold this high-level qualitative risk information into a system to produce a numeric result that would depict the relative change in hazard, associated with each major risk management action, so it could be presented graphically. This report presents the methodology developed to produce the graphic illustrations showing the relative hazard and risk reductions that occur as a result of a site's projected risk management actions. The evaluation of relative hazard values is described and illustrated first (Sections 2 and 3) followed by the risk measure evaluations (Sections 4 and 5).

The term "controlling constituent" is used often in this document. Controlling constituents are defined as those radionuclides and/or hazardous chemicals in a particular waste type that tend to control the impact or hazardousness of the consequence(s) associated with the waste material. That is, they are the radionuclides and/or hazardous chemicals that tend to drive the concern over the need to control the waste material. In the analysis methods discussed in this document, it is advantageous to limit the number of controlling constituents to as few as possible and still adequately represent the hazardousness of the waste material. In most risk assessments there are usually just one or two constituents that tend to drive the risk. It is these constituents that we are calling "controlling constituents." 


\subsection{Relative Hazard (RH) Calculation}

The methodology consists of using site-specific information (e.g., information from site disposition maps, site specific Project Baseline Summaries (PBSs), and other site documents that address elements of the overall risk story for a site) and applying factors from applicable site-specific risk assessment results or look-up tables to generate relative hazard $(\mathrm{RH})$ ratio values by waste type.

RH calculations are made using the following relationship of key risk-related parameters that can be extracted from the information provided for the risk profiles:

$$
R H=\frac{\sum_{c c=1}^{n} Q_{c c t} R F_{c c c t} H M_{c c t} H C_{c c t}}{\sum_{c c=1}^{n} Q_{c c t 0} R F_{c c c t 0} H M_{c c t 0} H C_{c c t 0}}
$$

Where,

\begin{tabular}{|c|c|c|}
\hline $\mathrm{Q}_{\mathrm{cct}}$ & $=$ & $\begin{array}{l}\text { quantity of the controlling constituents (radionuclides, in curies } \\
\text { and hazardous chemicals, in kilograms) at time t (i.e., time when } \\
\text { specified risk management action is completed) }\end{array}$ \\
\hline $\mathrm{Q}_{\mathrm{cct} t}$ & $=$ & $\begin{array}{l}\text { quantity of the controlling constituents (radionuclides, in curies } \\
\text { and hazardous chemicals, in kilograms) at time t0 (i.e., the original } \\
\text { baseline or starting time) }\end{array}$ \\
\hline $\mathrm{RF}_{\mathrm{cct}}$ & $=$ & $\begin{array}{l}\text { fraction of controlling constituent quantity that is releasable to } \\
\text { the controlling pathway at time } t\end{array}$ \\
\hline $\mathrm{RF}_{\text {cct0 }}$ & $=$ & $\begin{array}{l}\text { fraction of the controlling constituent quantity that is releasable to } \\
\text { the controlling pathway at time t } 0\end{array}$ \\
\hline $\mathrm{HM}_{\mathrm{cct}}$ & $=$ & $\begin{array}{l}\text { hazard measure factor for controlling constituent and controlling } \\
\text { pathway at time } t \text { (hazard measure factors from look-up tables) }\end{array}$ \\
\hline $\mathrm{HM}_{\text {cct0 }}$ & $=$ & $\begin{array}{l}\text { measure factor for controlling constituent and controlling } \\
\text { y at time t } 0 \text { (hazard measure factors from look-up tables) }\end{array}$ \\
\hline $\mathrm{HC}_{\mathrm{cct}}$ & $=$ & $\begin{array}{l}\text { hazard control factor for risk management control action specific at } \\
\text { time t (hazard control factors may be estimated from site risk data } \\
\text { or approximated using supplied look-up tables) }\end{array}$ \\
\hline $\mathrm{HC}_{\mathrm{cct} 0}$ & $=$ & $\begin{array}{l}\text { hazard control factor for risk management control action specific at } \\
\text { time t0 (hazard control factors may be estimated from site risk data } \\
\text { or approximated using supplied look-up tables) }\end{array}$ \\
\hline & & uumber of controlling constituents \\
\hline
\end{tabular}

Note: If only one controlling constituent is identified, the equation will not need to be summed over the number of controlling constituents.

The $\mathrm{RH}$ equation calculates a relative ratio representative of the hazard reduction associated with a specified risk management action compared to a baseline. It does not calculate an absolute hazard value. The level of data available in the disposition maps and PBSs are not detailed enough to support the calculation of absolute hazard values. In 
the risk profiles, the current state is assumed as the baseline for which to compare each risk management action (i.e., each factor ${ }_{\text {cct }}$ is compared to its corresponding baseline factor $\left._{\text {cct } 0}\right)$. If it is desired to compare each risk management action step with the previous risk management action time step, the baseline factors (i.e., factor ${ }_{\mathrm{cct} 0}$ ) can simply be replaced with the corresponding previous time factor (i.e., factor $\left.{ }_{\mathrm{cct}-1}\right)$. Each factor of the $\mathrm{RH}$ equation is discussed separately below.

\subsection{Quantity (Q) Data}

The best available site-specific quantity data should be used when calculating the RH ratios. In order for the $\mathrm{RH}$ ratios to be comparable across the different waste types, the quantity data should be specific to each controlling constituent and should be provided in units of curies for radionuclides or grams for hazardous chemicals. If exact amounts of each controlling constituent are not available, rough estimates of the fraction of each controlling constituent contained in the total waste quantity can be made. These fractions can then be used to adjust the total waste quantity to estimate the quantity of each respective controlling constituent. If controlling constituent quantity data in curies (radionuclides) or grams (hazardous chemicals) are just not available and it is not possible to estimate the fractions of each controlling constituent in the total waste quantity, the total waste quantity of each waste type can be used as a rough surrogate, as long as the units of this quantity remain the same through out the analysis of the respective waste type. However, this will generally make the RH result non-comparable across waste types and may not provide very accurate $\mathrm{RH}$ ratios for risk management actions that involve treatment of the controlling constituent(s).

\subsection{Release Fraction (RF)}

In some cases, the total quantity of a controlling constituent is not all releasable to the controlling exposure pathway (i.e., dominant exposure pathway) of concern. In these cases, a release fraction (i.e., the fraction of the total quantity of the controlling constituent that is releasable to the controlling pathway) should be provided for use in the $\mathrm{RH}$ equation to adjust the quantity, so that only the fraction of the controlling constituent quantity that can actually be released to the exposure pathway is considered. If all of the controlling constituent(s) quantity(ies) is (are) available for release to the controlling exposure pathway, which is true for many waste type situations, simply assign the RF factor a "1."

\subsection{Hazard Measure (HM) Factors}

The HM considers the inherent toxicity or carcinogenic potential of the controlling contaminant(s) identified, as well as its potential to expose members of the public through various exposure pathways. Because constituent HMs are determined a priori, $\mathrm{HM}$, along with $\mathrm{Q}$, is probably one of the least subjective of the RH equation factors. HM factor look-up tables are provided. 
The HM factors were derived differently for radionuclides and chemicals. Chemical HMs were based directly on the reportable quantities (RQ's) of 40 CFR part 302, "Designation, Reportable Quantities, and Notification." Radionuclide HMs were determined for five exposure pathways using ICRP-30 dose calculation methods and near-field exposure modeling assumptions. Derivation of these radionuclide HM's was based on a method developed for the Modified Hazard Ranking System (Hawley and Napier 1985; Hawley et al. 1986; Stenner et al. 1986). Because chemical and radionuclide HMs are determined differently, details of the two methods and differences between them are discussed below.

\subsubsection{Radionuclides}

The HM for radionuclides can be considered similar to an exposure pathway-specific dose factor, although the modeling is not detailed enough to provide an absolute dose estimate. As stated above, the basis for determining the HM of radionuclides was originally developed for the Modified Hazard Ranking System (MHRS). The MHRS was developed to work within the framework of the EPA's Hazard Ranking System (HRS) (EPA 1982), but also to provide a more appropriate treatment of radionuclides in ranking mixed waste sites for the National Priority List (NPL) under CERCLA. Therefore, like the MHRS and HRS, radionuclides were evaluated under five potential exposure pathways: air, surface water, groundwater, fire/explosion, and direct contact.

The MHRS was designed for generic application anywhere the EPA HRS could be used, included a limited suite of radionuclides, and used the ICRP Publication 2 (ICRP 1959) "critical organ" concept in assigning a potential "hazard ranking" to radionuclides. While the general concept used in the MHRS was retained, several enhancements were made to the $\mathrm{HM}$ factors presented for use in the RH calculations. Additional radionuclides are included, although, like the MHRS-based HM factors, the RH-based HM factors are generally limited to those radionuclides with a half-life of 1 year or greater, unless they were specifically noted as being potentially important in one of the specific waste materials considered. The dose calculation methodology was updated to ICRP Publication 30 (ICRP 1979), using the GENII computer codes (Napier et al. 1988a; $1988 \mathrm{~b} ; 1988 \mathrm{c})$ to perform updated calculations for the five exposure pathways. Radionuclide HMs are now based upon effective dose equivalent (EDE) rather than critical organ dose. The methodology used to produce the RH-based HM values utilized default inputs of the GENII code, and, for the groundwater exposure pathway, used groundwater transfer partition coefficients $\left(\mathrm{K}_{\mathrm{d}}\right)$ from Serne and Wood, 1990.

Like the MHRS-based factors, the RH-based HM factors are based upon near-field scenarios. In a near-field scenario, interest is focused on the doses an individual could receive at a particular location as a result of initial contamination or external sources (i.e., buried solid waste, contaminated soil, contaminated water, or contamination in air). This differs from a far-field scenario, defined as determining impacts of a particular release of radioactive or hazardous material into a wide environment, such as the dose from releases from a stack to individuals or populations downwind. Near-field assumptions were used, since the only basic difference between near-field and far-field scenarios is dilution. In an 
$\mathrm{RH}$ analysis, the affect of dilution distance can be accounted for in the Hazard Control (HC) parameter associated with relocation of material further from a receptor.

Descriptions of the exposure assumptions and radionuclide categories for each of the five exposure pathways are provided in the sections below, along with the respective HM factor look-up tables. In each exposure pathway table, radionuclides are categorized by the approximate dose received per unit concentration. Each category differs from the others by approximately an order of magnitude in the "relative dose impact." All exposure pathway specific HM-factor tables have been normalized, so that the highest category is $\mathrm{V}$ and the lowest is 0 ; corresponding to the exponent of the value of the HM factor assigned to each category (i.e., category V has an HM value of 100,000, while category 0 has an HM value of 1).

\subsubsection{Air Exposure Pathway}

This is a chronic exposure pathway that primarily poses long-term, large-scale risks to the public. Assumptions are that the exposed individual 1) lives continuously in contaminated air (chronic inhalation), 2) is continuously exposed to external radiation from radionuclides deposited on the ground surface, and 3) is continuously immersed in the airborne radioactive plume. The values of the HM factor for the air exposure pathway are given in Table 2.1 for selected radionuclides.

\subsubsection{Surface-Water Exposure Pathway}

This is a chronic exposure pathway that primarily poses long-term risks to public users of local surface water sources. Assumptions are that the exposed individual: 1) eats food irrigated with contaminated surface water, at an irrigation rate of $150 \mathrm{~L} / \mathrm{m}^{2} / \mathrm{mo}$ for 6 mo/yr: 2) eats fish from the contaminated water; 3 ) is exposed to external radiation from contaminated sediments along the bank: and 4) gets drinking water from the contaminated surface water. Resuspension or external radiation from radionuclides deposited on the soil from irrigation are not considered. The values of the HM factor for the surface-water exposure pathway are given in Table 2.2 for selected radionuclides.

\subsubsection{Groundwater-to-Surface-Water Exposure Pathway}

This is a chronic exposure pathway that primarily poses long-term risks to public users of the local surface water sources. Groundwater is assumed to connect with surface water through infiltration, and exposure is via the surface water exposure pathway. No direct groundwater exposure via groundwater wells is assumed. Assumptions are that the exposed individual: 1) eats food irrigated with surface water contaminated via connection with groundwater, at an irrigation rate of $150 \mathrm{~L} / \mathrm{m}^{2} / \mathrm{mo}$ for $6 \mathrm{mo} / \mathrm{yr}$; 2) eats fish from the contaminated water; 3 ) is exposed to external radiation from contaminated sediments along the bank: and 4) gets drinking water from the contaminated surface water. Resuspension or external radiation from radionuclides deposited on the soil from irrigation is not considered. 
Table 2.1. Air Exposure Pathway Groups for Radionuclides

\begin{tabular}{ccl} 
Category & $\begin{array}{c}\text { Hazard } \\
\text { Measure (HM) }\end{array}$ & \multicolumn{1}{c}{ Radionuclide Grouping } \\
\hline V & $10^{5}$ & ${ }^{22} \mathrm{Na},{ }^{54} \mathrm{Mn},{ }^{60} \mathrm{Co},{ }^{94} \mathrm{Nb},{ }^{125} \mathrm{Sb},{ }^{134} \mathrm{Cs},{ }^{137} \mathrm{Cs},{ }^{152} \mathrm{Eu},{ }^{154} \mathrm{Eu}$ \\
IV & $10^{4}$ & ${ }^{155} \mathrm{Eu},{ }^{232} \mathrm{Th},{ }^{233} \mathrm{U},{ }^{234} \mathrm{U},{ }^{235} \mathrm{U},{ }^{238} \mathrm{U},{ }^{237} \mathrm{~Np},{ }^{239} \mathrm{~Np},{ }^{238} \mathrm{Pu}$, \\
III & $10^{3}$ & ${ }^{240} \mathrm{Pu},{ }^{10} \mathrm{Pu},{ }^{36} \mathrm{Cl},{ }^{109} \mathrm{Cd},{ }^{129} \mathrm{Cm},{ }^{241} \mathrm{Pu},{ }^{246} \mathrm{Cm},{ }^{245} \mathrm{Cm},{ }^{242} \mathrm{Cm},{ }^{252} \mathrm{Cf}$ \\
II & 100 & ${ }^{55} \mathrm{Fe},{ }^{59} \mathrm{Ni},{ }^{90} \mathrm{Sr},{ }^{93} \mathrm{Mo},{ }^{99} \mathrm{Tc},{ }^{147} \mathrm{Pm}$ \\
I & 10 & ${ }^{14} \mathrm{C},{ }^{135} \mathrm{Cs},{ }^{151} \mathrm{Sm}$ \\
O & 1 & ${ }^{3} \mathrm{H},{ }^{63} \mathrm{Ni}$
\end{tabular}

Table 2.2. Surface Water Exposure Pathway Groups for Radionuclides

\begin{tabular}{|c|c|c|}
\hline Category & $\begin{array}{c}\text { Hazard } \\
\text { Measure (HM) }\end{array}$ & Radionuclide Grouping \\
\hline $\mathrm{V}$ & $10^{5}$ & ${ }^{134} \mathrm{Cs},{ }^{137} \mathrm{Cs},{ }^{237} \mathrm{~Np}$ \\
\hline IV & $10^{4}$ & ${ }^{129} \mathrm{I},{ }^{135} \mathrm{Cs},{ }^{226} \mathrm{Ra},{ }^{232} \mathrm{Th},{ }^{241} \mathrm{Am},{ }^{243} \mathrm{Cm},{ }^{244} \mathrm{Cm},{ }^{245} \mathrm{Cm},{ }^{252} \mathrm{Cf}$ \\
\hline III & $10^{3}$ & $\begin{array}{l}{ }^{14} \mathrm{C},{ }^{22} \mathrm{Na},{ }^{36} \mathrm{Cl},{ }^{60} \mathrm{Co},{ }^{109} \mathrm{Cd},{ }^{152} \mathrm{Eu},{ }^{154} \mathrm{Eu},{ }^{233} \mathrm{U},{ }^{234} \mathrm{U},{ }^{235} \mathrm{U} \\
{ }^{238} \mathrm{U},{ }^{239} \mathrm{~Np},{ }^{238} \mathrm{Pu},{ }^{239} \mathrm{Pu},{ }^{240} \mathrm{Pu},{ }^{242} \mathrm{Cm}\end{array}$ \\
\hline II & 100 & $\begin{array}{l}{ }^{10} \mathrm{Be},{ }^{54} \mathrm{Mn},{ }^{55} \mathrm{Fe},{ }^{63} \mathrm{Ni},{ }^{90} \mathrm{Sr},{ }^{94} \mathrm{Nb},{ }^{99} \mathrm{Tc},{ }^{125} \mathrm{Sb},{ }^{147} \mathrm{Pm},{ }^{151} \mathrm{Sm} \\
{ }^{155} \mathrm{Eu},{ }^{241} \mathrm{Pu}\end{array}$ \\
\hline I & 10 & ${ }^{59} \mathrm{Ni},{ }^{93} \mathrm{Mo}$ \\
\hline 0 & 1 & ${ }^{3} \mathrm{H}$ \\
\hline
\end{tabular}

The groundwater-to-surface-water exposure pathway radionuclide categories were adjusted for the tendency of radionuclides to adsorb to soil particles (partition coefficient, Kd) during groundwater transport. Partition coefficients were obtained (Serne and Wood 1990 ) and converted to groundwater transfer coefficients from 1 to 100 (Hawley and Napier 1985; Hawley et al. 1986) to be consistent with the multiplicative RH strategy. The Kd values used for each radionuclide and the derived groundwater transfer coefficients are shown in Table 2.3. The HM factor for groundwater does not consider the time it takes the radionuclide to move through the vadose zone to the saturated zone and to a point where it could fit the near-field scenario. The values of the HM factor for the groundwater-to-surface water exposure pathway are given in Table 2.4 for selected radionuclides. 
Table 2.3. Partition Coefficients $\left(\mathrm{K}_{d} s\right)$ and Derived Groundwater Transfer Coefficients Used in the Groundwater Exposure Pathway Radionuclide Categories

\begin{tabular}{|c|c|c|}
\hline Constituent/Radionuclide & $\mathbf{K}_{\mathbf{d}}$ & $\begin{array}{c}\text { Groundwater } \\
\text { Transfer Coefficient }\end{array}$ \\
\hline${ }^{3} \mathrm{H}$ & $0^{(\mathbf{a})}$ & 100 \\
\hline $\mathrm{Be}$ & $30^{(b)}$ & 3 \\
\hline${ }^{14} \mathrm{C}$ & $0^{(a)}$ & 100 \\
\hline $\mathrm{Na}$ & $3^{(a)}$ & 33 \\
\hline $\mathrm{Cl}$ & $0^{(a)}$ & 100 \\
\hline $\mathrm{Mn}$ & $20^{(\mathrm{a})}$ & 5 \\
\hline $\mathrm{Fe}$ & $20^{(a)}$ & 5 \\
\hline Co & $10^{(\mathrm{a})}$ & 10 \\
\hline $\mathrm{Ni}$ & $15^{(\mathrm{a})}$ & 7 \\
\hline $\mathrm{Sr}$ & $10^{(\mathrm{a})}$ & 10 \\
\hline $\mathrm{Sb}$ & $0^{(b)}$ & 100 \\
\hline $\mathrm{Nb}$ & $100^{(b)}$ & 1 \\
\hline Mo & $0^{(a)}$ & 100 \\
\hline $\mathrm{Tc}$ & $0^{(a)}$ & 100 \\
\hline $\mathrm{Cd}$ & $15^{(\mathrm{a})}$ & 7 \\
\hline I & $0^{(\mathrm{a})}$ & 100 \\
\hline Cs & $50^{(a)}$ & 2 \\
\hline Lanthanides $\mathrm{Eu}, \mathrm{Pm}, \mathrm{Sm}$ & $50^{(\mathrm{a})}$ & 2 \\
\hline $\mathrm{Ra}$ & $20^{(\mathrm{a})}$ & 5 \\
\hline Th & $50^{(\mathrm{a})}$ & 2 \\
\hline$U$ & $0^{(a)}$ & 100 \\
\hline $\mathrm{Np}$ & $3^{(a)}$ & 33 \\
\hline $\mathrm{Pu}$ & $100^{(a)}$ & 1 \\
\hline $\mathrm{Am}, \mathrm{Cm}$ & $100^{(a)}$ & 1 \\
\hline $\mathrm{Ac}, \mathrm{Cf}$ & $100^{(b)}$ & 1 \\
\hline
\end{tabular}

(a) Seme, R. J., and M. I. Wood. 1990.

(b) Serne, R. J. 1994. 
Table 2.4. Groundwater-to-Surface Water Exposure Pathway Groups for Radionuclides

Hazard

\begin{tabular}{|c|c|c|}
\hline Category & Measure (HM) & Radionuclide Grouping \\
\hline $\mathrm{V}$ & $10^{5}$ & ${ }^{237} \mathrm{~Np}$ \\
\hline IV & $10^{4}$ & $129 \mathrm{I}$ \\
\hline III & $10^{3}$ & $\begin{array}{l}{ }^{14} \mathrm{C},{ }^{36} \mathrm{Cl},{ }^{134} \mathrm{Cs},{ }^{137} \mathrm{Cs},{ }^{232} \mathrm{Th},{ }^{233} \mathrm{U},{ }^{234} \mathrm{U},{ }^{235} \mathrm{U},{ }^{238} \mathrm{U}, \\
{ }^{241} \mathrm{Am}\end{array}$ \\
\hline II & 100 & ${ }^{22} \mathrm{Na},{ }^{60} \mathrm{Co},{ }^{99} \mathrm{Tc},{ }^{125} \mathrm{Sb},{ }^{135} \mathrm{Cs},{ }^{226} \mathrm{Ra},{ }^{243} \mathrm{Cm},{ }^{244} \mathrm{Cm},{ }^{245} \mathrm{Cm}$ \\
\hline I & 10 & ${ }^{54} \mathrm{Mn},{ }^{55} \mathrm{Fe},{ }^{90} \mathrm{Sr},{ }^{109} \mathrm{Cd},{ }^{152} \mathrm{Eu},{ }^{154} \mathrm{Eu},{ }^{238} \mathrm{Pu},{ }^{239} \mathrm{Pu},{ }^{240} \mathrm{Pu}$ \\
\hline 0 & 1 & ${ }^{3} \mathrm{H},{ }^{10} \mathrm{Be},{ }^{59} \mathrm{Ni},{ }^{63} \mathrm{Ni},{ }^{94} \mathrm{Nb},{ }^{93} \mathrm{Mo},{ }^{147} \mathrm{Pm},{ }^{151} \mathrm{Sm},{ }^{155} \mathrm{Eu},{ }^{241} \mathrm{Pu}$ \\
\hline
\end{tabular}

Table 2.5. Fire/Explosion Exposure Pathway Groups for Radionuclides

\begin{tabular}{|c|c|c|}
\hline Category & $\begin{array}{c}\text { Hazard } \\
\text { Measure (HM) }\end{array}$ & Radionuclide Grouping \\
\hline $\mathrm{v}$ & $10^{5}$ & $\begin{array}{l}{ }^{232} \mathrm{Th},{ }^{233} \mathrm{U},{ }^{234} \mathrm{U},{ }^{235} \mathrm{U},{ }^{238} \mathrm{U},{ }^{237} \mathrm{~Np},{ }^{238} \mathrm{Pu},{ }^{239} \mathrm{Pu},{ }^{240} \mathrm{Pu}, \\
{ }^{241} \mathrm{Am},{ }^{243} \mathrm{Cm},{ }^{244} \mathrm{Cm},{ }^{245} \mathrm{Cm},{ }^{252} \mathrm{Cf}\end{array}$ \\
\hline IV & $10^{4}$ & $\begin{array}{l}{ }^{22} \mathrm{Na},{ }^{54} \mathrm{Mn},{ }^{60} \mathrm{Co},{ }^{94} \mathrm{Nb},{ }^{125} \mathrm{Sb},{ }^{134} \mathrm{Cs},{ }^{137} \mathrm{Cs},{ }^{152} \mathrm{Eu} \\
{ }^{154} \mathrm{Eu},{ }^{226} \mathrm{Ra},{ }^{241} \mathrm{Pu},{ }^{242} \mathrm{Cm}\end{array}$ \\
\hline III & $10^{3}$ & ${ }^{10} \mathrm{Be},{ }^{90} \mathrm{Sr},{ }^{109} \mathrm{Cd},{ }^{129} \mathrm{l},{ }^{155} \mathrm{Eu},{ }^{239} \mathrm{~Np}$ \\
\hline II & 100 & ${ }^{36} \mathrm{Cl},{ }^{93} \mathrm{Mo},{ }^{99} \mathrm{Tc},{ }^{135} \mathrm{Cs},{ }^{147} \mathrm{Pm},{ }^{151} \mathrm{Sm}$ \\
\hline I & 10 & ${ }^{14} \mathrm{C},{ }^{55} \mathrm{Fe},{ }^{59} \mathrm{Ni},{ }^{63} \mathrm{Ni}$ \\
\hline 0 & 1 & ${ }^{3} \mathrm{H}$ \\
\hline
\end{tabular}

\subsubsection{Fire/Explosion Pathway}

The fire/explosion pathway is also intended to represent non-energetic acute releases resulting from facility accident sequences. This acute exposure pathway primarily poses near-term, large-scale public health risks. Assumptions are: 1) exposure lasts only a short time, approximately 0.5 hour, with the exposed individual at the center line of the released plume; and 2) the only relevant pathway in inhalation; to account for the high concentration of material in the plume, it was modeled as resuspension with a mass loading of $1 \mathrm{~g} / \mathrm{m}^{3}$. The values of the HM for the fire/explosion exposure pathway are given in Table 2.5 for key radionuclides.

\subsubsection{Direct Contact Exposure Pathway}

This is an acute exposure pathway that primarily poses near-term risks to individual workers or members of the public. Assumptions are: 1) the exposed individual is in direct contact with the material for a short period of time, approximately $1 \mathrm{hr}$., while digging or otherwise making loose material airborne; 2) exposure pathways are inhalation, external exposure, and resuspension of loose material with mass loading of 
$0.0001 \mathrm{~g} / \mathrm{m}^{3}$. The values of the HM factor for the direct contact exposure pathway are given in Table 2.6 for selected radionuclides.

\subsubsection{Hazardous Chemicals}

The HM factor values for hazardous chemicals are based on the RQs of 40 CFR Subpart 302.4, "Designation of Hazardous Substances" (40 CFR 1993). As stated by EPA, "RQs represent a determination only of possible or potential harm, not that releases of a particular amount of a hazardous substances necessarily will be harmful to the public health or welfare or to the environment." The RQs provide a simple, readily available method of comparing the potential hazard from a specific set of chemicals.

Table 2.6. Direct Contact Exposure Pathway Groups for Radionuclides

\begin{tabular}{ccc} 
Category & $\begin{array}{c}\text { Hazard } \\
\text { Measure (HM) }\end{array}$ & \multicolumn{1}{c}{ Radionuclide Grouping } \\
\hline V & $10^{5}$ & ${ }^{22} \mathrm{Na},{ }^{54} \mathrm{Mn},{ }^{60} \mathrm{Co},{ }^{94} \mathrm{Nb},{ }^{125} \mathrm{Sb},{ }^{134} \mathrm{Cs},{ }^{137} \mathrm{Cs},{ }^{152} \mathrm{Eu},{ }^{154} \mathrm{Eu}$ \\
IV & $10^{4}$ & ${ }^{155} \mathrm{Eu},{ }^{232} \mathrm{Th},{ }^{233} \mathrm{U},{ }^{234} \mathrm{U},{ }^{235} \mathrm{U},{ }^{238} \mathrm{U},{ }^{237} \mathrm{~Np},{ }^{239} \mathrm{~Np},{ }^{238} \mathrm{Pu}$, \\
III & $10^{3}$ & ${ }^{239} \mathrm{Pu},{ }^{240} \mathrm{Pu},{ }^{241} \mathrm{Am},{ }^{243} \mathrm{Cm},{ }^{244} \mathrm{Cm},{ }^{245} \mathrm{Cm},{ }^{252} \mathrm{Cf}$ \\
II & 100 & ${ }^{109} \mathrm{Cd},{ }^{129} \mathrm{I},{ }^{226} \mathrm{Ra},{ }^{241} \mathrm{Pu},{ }^{242} \mathrm{Cm}$ \\
I & 10 & ${ }^{10} \mathrm{Be},{ }^{36} \mathrm{Cl},{ }^{55} \mathrm{Fe},{ }^{59} \mathrm{Ni},{ }^{90} \mathrm{Sr},{ }^{93} \mathrm{Mo}$ \\
O & ${ }^{14} \mathrm{C},{ }^{63} \mathrm{Ni},{ }^{99} \mathrm{Tc},{ }^{135} \mathrm{Cs},{ }^{147} \mathrm{Pm},{ }^{151} \mathrm{Sm}$
\end{tabular}

The RQs are not exposure-pathway specific, with primary criteria for evaluation being aquatic toxicity, mammalian toxicity (oral, dermal, and inhalation), ignitability, reactivity, chronic toxicity, and potential carcinogenicity. Thus, the RQ-derived HMs for hazardous chemicals are fundamentally different from the HMs for radionuclides (as discussed above).

The HMs for chemicals were derived from the RQs as shown in Table 2.7. An adjustment was made to maintain a multiplicative scheme for the RH strategy. Relationships between the various RQs and HMs are maintained by this adjustment.

Not all chemicals identified for the various DOE facilities and areas will have RQs listed in 40 CFR 302. Some HM values were derived by comparison to similar chemicals. In cases where no values of RQ are available for a specific key chemical, surrogate values of $\mathrm{HM}$ can be developed using RQ values from a chemical with similar transport $\left(\mathrm{K}_{\mathrm{d}}\right.$, $\mathrm{K}_{\mathrm{oc}}, \mathrm{K}_{\mathrm{ow}}$, solubility limit, etc) and toxicity (e.g., slope factors and reference doses). Transport and toxicity parameter values can be reviewed using the Multimedia-Modeling Environmental Database Editor (MMEDE, Warren and Strenge 1994) which access the MEPAS database (Strenge and Peterson 1989). Table 2.8 provides a list of constituents of possible importance to DOE sites, and indicates the use of surrogate chemicals in several instances. The table lists current RQ values from 40 CFR 302 for several chemicals with HM values determined using the convention of Table 2.7. For those chemicals not included in 40 CFR 302, the estimated HM is given with an indication of 
the basis. The HM values for benzo(b)fluoranthene and benzo(k)fluoranthene were estimated from the HM of benzo(a)pyrene and the toxicity equivalence among the three compounds. From the MEPAS database, the oral slope factors for the three chemicals are: benzo(a)pyrene $-7.3 \mathrm{~kg}-\mathrm{d} / \mathrm{mg}$, benzo(b)fluoranthene $-0.73 \mathrm{~kg}-\mathrm{d} / \mathrm{mg}$, and benzo(k)fluoranthene $-0.073 \mathrm{~kg}-\mathrm{d} / \mathrm{mg}$. The HM for benzo(a)pyrene is multiplied by the chemical oral slope factor and divided by the benzo(a)pyrene slope factor to estimate the HM for the chemical. The inorganic chemicals in the list are assumed to be in ionic form. Some of these are expected to be in relatively non-toxic forms in the environment (e.g. sodium, potassium, magnesium, and nitrate) and have HM values set to the minimum value (0.5) from Table 2.7 .

Table 2.7. Hazard Measures for Chemicals Based on Reportable Quantity

\begin{tabular}{ccc} 
Category & RQ & HM \\
\hline A & 1 & 1000 \\
B & 10 & 100 \\
C & 100 & 10 \\
D & 1000 & 1 \\
E & 5000 & 0.5
\end{tabular}


Table 2.8 Hazard Measures Determination for Representative Constituents

\begin{tabular}{|c|c|c|c|c|}
\hline CAS & Name & Final RQ & HM & HM Basis \\
\hline 56235 & Carbon Tetrachloride & 10 & 100 & RQ \\
\hline 67561 & Methanol & 5000 & 0.5 & RQ \\
\hline 64175 & Ethanol & - & 0.5 & Methanol HM \\
\hline 67630 & Isopropanol & - & 0.5 & Methanol HM \\
\hline 75058 & Acetonitrile & 5000 & 0.5 & RQ \\
\hline 91203 & Naphthalene & 100 & 10 & RQ \\
\hline 91576 & 2-Methylnaphthalene & - & 10 & Naphthalene HM \\
\hline 107211 & Ethylene glycol & 5000 & 0.5 & RQ \\
\hline 110543 & Hexanes & 5000 & 0.5 & RQ \\
\hline 117817 & Bis(2-ethylhexyl)phthalate & 100 & 10 & RQ \\
\hline 126738 & Tributylphosphate & - & $\mathbf{1 0}$ & Tetrachloroethylene HM \\
\hline 127184 & Tetrachloroethylene & 100 & 10 & RQ \\
\hline 79016 & Trichloroethylene & 100 & 10 & RQ \\
\hline 71432 & Benzene & 10 & 100 & RQ \\
\hline 50328 & Benzo(a)pyrene & 1 & 1000 & $\mathbf{R Q}$ \\
\hline 205992 & Benzo(b)fluoranthene & - & 100 & $\begin{array}{l}\text { Benzo(a)pyrene HM and toxicity } \\
\text { equivalence }\end{array}$ \\
\hline 207089 & Benzo(k)fluoranthene & - & $\mathbf{1 0}$ & $\begin{array}{l}\text { Benzo(a)pyrene HM and toxicity } \\
\text { equivalence }\end{array}$ \\
\hline 1809194 & Dibutyl Phosphate & - & 10 & Tetrachloroethylene HM \\
\hline 6834920 & Silica & - & 0.5 & Minimum HM value \\
\hline 7429905 & Aluminum ion & 5000 & 0.5 & RQ for aluminum sulfate \\
\hline 7439987 & Molybdenum ion & - & 1 & HM value for chromium III and VI \\
\hline 7440393 & Barium & 1000 & $\mathbf{1}$ & RQ \\
\hline 7440473 & Chromium VI ion & 1000 & 1 & RQ for chromic acetate and sulfate \\
\hline 7440611 & Uranium ion & 100 & $\mathbf{1 0}$ & RQ for uranyl acetate and nitrate \\
\hline 7440622 & Vanadium ion & 1000 & 1 & RQ for vanadium compounds \\
\hline 7440677 & Zirconium ion & 5000 & 0.5 & RQ for zirconium compounds \\
\hline 7440702 & Calcium ion & - & 0.5 & Minimum HM value \\
\hline 7447407 & Potassium ion & - & 0.5 & Minimum HM value \\
\hline 7447418 & Lithium ion & 10 & 100 & RQ for lithium chromate \\
\hline 7601549 & Phosphate ion & 5000 & 0.5 & RQ for phosphoric acid \\
\hline 7647145 & Sodium ion & - & 0.5 & Minimum HM value \\
\hline 7782414 & Fluoride ion & 1000 & 1 & RQ for fluorides of sodium and zinc \\
\hline 7786303 & Magnesium ion & - & 0.5 & Minimum HM value \\
\hline 12808798 & Sulfate ion & - & 0.5 & Minimum HM value \\
\hline 14797558 & Nitrate ion & - & 0.5 & Minimum HM value \\
\hline 15438310 & Iron ion & 1000 & 1 & RQ for ferric chloride and sulfate \\
\hline 16065831 & Chromium III ion & 1000 & 1 & RQ for chromus chloride \\
\hline 14797650 & Nitrite ion & 1000 & 1 & RQ for sodium nitrite \\
\hline 7440360 & Antimony ion & 1000 & 1 & RQ for common antimony salts \\
\hline
\end{tabular}




\subsection{Hazard Control Factors}

The Hazard Control (HC) factors represent the worth, in terms of reduction in hazard, of specific risk management actions. These actions include risk management activities such as vitrification or grouting of waste materials; separation, reduction and/or removal of specific constituents from a waste stream; relocation of waste material away from receptors or vulnerable pathways; repackaging and/or stabilization of waste material.

In calculating the relative hazard (RH) of a waste type at a site, it is recommended that these $\mathrm{HC}$ factors be estimated from existing risk assessment data, where possible. In many cases there will be specific risk assessments for which generalizations can be made to roughly estimate the worth of a specific risk management action. Often there are risk estimates for specified accident conditions in a Safety Analysis Report (SAR) or safety basis document that can be examined to get a rough estimate of the worth of a specific action. In cases where no such risk assessment data are available, HC look-up tables are provided to use in estimating the $\mathrm{HC}$ factor.

The $\mathrm{HC}$ factor is used to assess changes in the relative hazard of a contaminant or waste based on changes in its physical condition or location due to waste management or environmental restoration actions. The $\mathrm{HC}$ factor for a specific hazard reduction measure (e.g., capping) represents the reduction in hazard associated with that measure (i.e., the post-action hazard divided by the pre-action hazard). This factor, in conjunction with the other factors representing contaminant inventory and the nature of the contaminant and potential contaminant exposure mechanism, allows evaluating the potential reduction in hazard associated with a variety of potential waste management or environmental restoration actions.

\subsubsection{Hazard vs. Risk}

The term "hazard" as used here relates to potential health effects associated with a contaminant or waste material, assuming that it is already released to the environment. In contrast, the estimates of risk that are typically used to assess the need for or effectiveness of potential environmental restoration or waste management activities are computed taking into account both potential health effects (i.e., hazard) and the likelihood or probability of contaminant release and subsequent exposure. In simple terms, hazard and risk are related as follows:

RISK $=\begin{aligned} & \text { PROBABILITY OF } \\ & \text { RELEASE OR } \\ & \text { EXPOSURE }\end{aligned} \quad \mathrm{X} \quad$ HAZARD

Therefore, the term hazard as used here relates only to the intrinsic danger to health that would be posed by the contaminant or waste material in the environment in its current physical form and location. Changes in physical form or location of a contaminant or 
waste that alter its hazard can also change its associated risk. However, it is not necessarily true that that a contaminant or waste with a relatively high hazard poses a high risk in the sense that is usually discussed in "risk assessments."

This relationship between risk and hazard can be used to facilitate calculating HCs. If the risks are compared for a contaminant or waste in alternative physical conditions or locations, but having the same probability of release or exposure, the relative hazards posed by those alternative conditions or locations are related in the same proportion as the relative risks.

Therefore, using standard risk estimating techniques in a manner that makes the probability of release or exposure constant allows direct estimation of the change in hazard associated with potential waste management or environmental restoration actions. The simplest way to "fix" the probability of release or exposure is to assume that the contaminant or waste has already been released. This is the approach that was used to estimate the changes in hazard (i.e., HCs) discussed in the following sections.

\subsubsection{Factors Affecting the $\mathrm{HC}$}

Five aspects of a contaminant or waste that have significant impacts relative to assessing its hazard are described in the following sections.

\subsubsection{Toxicity or Radiological Nature}

A contaminant's toxic or radiological characteristics determine the severity of its health effects when exposure occurs. Differences among contaminants in this regard are accounted for in the health effects data used in risk assessment methodologies. While typical waste management or environmental restoration activities may affect the amount of contaminant present, they don't generally affect its toxic or radiological nature. Therefore, this aspect of potential hazard is not addressed in assessing HCs for such actions. However, since this factor affects hazard, but not $\mathrm{HCs}$, this aspect of hazard is addressed by the HM factor in the relative hazard calculation.

\subsubsection{Chemical Nature}

The second key aspect of a contaminant affecting its hazard, or the impact of hazard control measures on it, is its chemical nature. Organic and inorganic contaminants generally behave differently both in their environmental transport and their response to treatment. In addition, the hazard associated with a radioactive elements changes spontaneously as it decays.

\subsubsection{Mobility}

A third aspect of a contaminant or waste affecting its hazard is its mobility in the environment. Contaminants that move more readily through the environment are more likely transport to off-site receptors and thereby pose health risks to those receptors than 
those that are relatively immobile. In addition, slow transport of radioactive elements allows time for these contaminants to decay prior to exposing receptors.

\subsubsection{Physical Form}

The physical form of a contaminant or waste has a significant impact on its hazard. The physical form of a contaminant or waste affects its availability for transport (i.e., the rate at which it is released). For example, liquid wastes are generally easier to transport than solid wastes, and are therefore more hazardous. In addition, solid waste that has been treated to immobilize contaminants (e.g., cemented or vitrified) allows contaminants to be released more slowly for transport and is therefore less hazardous.

\subsubsection{Location}

The final aspect of a contaminant or waste that affects its hazard is its location. A contaminant released to the environment in an isolated location with long transport pathways to receptors is intrinsically less hazardous than the same contaminant in a location that allows rapid transport of it to receptors. In addition, the hazard reduction associated with a waste management or environmental restoration action will vary depending on the waste's location.

\subsubsection{Approach for Estimating HCs}

Calculating site-specific HCs for a variety of potential waste management or environmental restoration actions requires taking all these considerations into account. The approach used here is to compare the calculated risks for site-specific conditions before and after such actions are taken to infer the corresponding reduction in hazard, as suggested by the relationship between risk and hazard discussed above.

Such risk calculations can be performed with any risk calculation methodology that allows parametric variation of the key parameters discussed above. For the illustrative calculations discussed below, the Remedial Action Assessment System (RAAS) ${ }^{1}$ was utilized. RAAS was developed by Pacific Northwest National Laboratory (PNNL) for DOE as an analytical tool for defining and evaluating alternative remedial action strategies for DOE waste sites. The RAAS methodology is useful for this sort of analysis because it allows direct variation of the key waste form and waste location parameters described above.

RAAS includes elements of the Multimedia Environmental Pollutant Assessment System $(\mathrm{MEPAS})^{2}$ for calculating risk for the maximum exposed individual (MEI) as a result of transport of contaminants to potential receptors. As discussed above, comparison of

\footnotetext{
${ }^{1}$ Battelle Memorial Institute, RAAS Version 1.1, Battelle, PNL-8751, Rev. 3 (October 1996).

${ }^{2}$ Droppo, J.G., Jr. D. L. Strenge, J. W. Buck, B. L. Hoopes, R.D. Brockhaus, M. B. Walter, and G. Whelan. 1989b. Mulitmedia Environmental Pollutant Assessment System (MEPAS) Application Guidance Volume 1 - User's Guide. PNL-7216, Pacific Northwest Laboratory, Richland, Washington.
} 
these MEI risks as key waste form or location factors are varied allows calculation of the corresponding $\mathrm{HC}$.

\subsubsection{Waste Form Variations}

Four different waste forms were analyzed in the following illustrations: liquid waste, soil waste, cemented or grouted waste, and vitrified waste. These classifications represent the most likely forms that will be encountered in assessing hazard reduction measures, and many of the key hazard reduction measures result in a transition from one of these physical states to another.

The relative hazards associated with these states were calculated by comparing the risk associated with equivalent amounts of contaminant already released to the environment in these states. For the solid waste forms (soil waste, cemented or grout wastes, and vitrified waste), in-situ wastes of the corresponding waste forms or states were modeled, and the corresponding risk calculated. Since these waste were already released, the "probability of release or exposure" aspect of the risk calculation is the same (i.e., probability of release or exposure is "1.0"), and therefore the risk measure also represent the relative hazards. The liquid waste state was modeled as a pond containing the same amount of the contaminant as the soil site. Again, the contaminant is modeled as already released, so the corresponding calculated risk can be used to assess changes in hazard. These calculations, performed for each site of interest, result in the following factors that are subsequently used in HC calculation:

$$
\begin{aligned}
\mathrm{GF} & =\frac{\text { risk associated with unit of contaminant in cemented/grouted waste }}{\text { risk associated with unit of contaminant in soil waste }} \\
\mathrm{VF} & =\frac{\text { risk associated with unit of contaminant in vitrified waste }}{\text { risk associated with unit of contaminant in soil waste }} \\
\mathrm{SF} & =\frac{\text { risk associated with unit of contaminant in liquid waste }}{\text { risk associated with unit of contaminant in soil waste }}
\end{aligned}
$$

\subsubsection{Hazard Reduction Measures}

HCs were estimated for a variety of waste treatment or environmental restoration activities involving the waste form changes described above. In addition, the following similar factors were defined or estimated (also using the RAAS methodology) for other actions typically occurring as part of waste treatment and environmental restoration:

$$
\begin{aligned}
\text { FMR } & =\text { Fraction of Medium Removed (in contaminated medium) } \\
\text { FCR } & =\begin{array}{l}
\text { Fraction Contaminant Remaining (after separation/destruction } \\
\text { treatment) }
\end{array} \\
\mathrm{CF} & =\frac{\text { risk associated with unit of contaminant in capped site }}{\text { risk associated with unit of contaminant in soil waste site }}
\end{aligned}
$$




$$
\mathrm{RF}=\frac{\text { risk associated with unit of contaminant in alternative waste site }}{\text { risk associated with unit of contaminant in original soil waste }}
$$

The first two of these (FMR and FCR) relate to actions that change the inventory or contaminant. In general, the hazard associated with a contaminant is in proportion to its inventory. If waste is removed from a contaminated site for treatment, the fraction remaining (1-FMR) retains its initial hazard level, while the fraction removed (FMR) may have a different hazard level depending on how it is treated and subsequently disposed). Note that this formulation assumes that contaminant removed is proportional to medium removed. If this is not the case, then the fraction of the contaminant remaining should be used rather than the fraction of the medium remaining. Similarly, FCR is used to assess the change in hazard associated with in situ or ex situ treatment that separates or destroys contaminant, thereby changing the contaminant inventory and corresponding hazard. These two factors (i.e., FMR and FCR) are provided to allow the user to make adjustments for inventory reductions within the $\mathrm{HC}$ factor; however, these inventory adjustments can also be made by directly adjusting the respective $Q$ values of the RH equation. It is left to the user's discretion to decide where best to account for inventory changes associated with specific risk/hazard management actions, but care should be taken not to "double count" the inventory reductions. Table 2.9 defines the HC for a variety of potential waste management or environmental restoration actions, in terms of the various hazard reduction factors previously defined.

\subsubsection{Contaminant Categories}

Ideally, the various factors defined above could be calculated for every contaminant of concern and then used as appropriate to estimate HCs for waste management or environmental restoration actions of interest. The RAAS methodology contains the necessary physical, chemical, and health effect data for over 400 organic, inorganic, and radioactive contaminants of potential concern. However, performing such comprehensive calculations is time consuming, and probably not warranted in terms of the incremental insight provided. Rather, representative contaminants can be selected and used as surrogates for specific contaminants. As discussed previously, the key contaminant-specific differences of concern relate to the chemical or radiological nature of the contaminant and its mobility.

For the purposes of the illustrative HC estimates developed here, a set of contaminant categories were developed that represent potential variation in these key contaminant characteristics, and a representative contaminant selected for each category. These categories and representative contaminants are shown in Table 2.10. 
Table 2.9. Hazard Reduction Measures with Generic Hazard Control (HC) Factors

\begin{tabular}{|c|c|c|}
\hline \multicolumn{2}{|l|}{ Hazard Reduction Measure } & HC Factor \\
\hline \multirow{3}{*}{$\begin{array}{l}\text { removal, treatment, and } \\
\text { disposal of treated medium in } \\
\text { original environmental setting }\end{array}$} & $\begin{array}{l}\text { treatment to separate or } \\
\text { destroy contaminants }\end{array}$ & 1 - FMR (1 - FCR) \\
\hline & $\begin{array}{l}\text { cement/package removed } \\
\text { medium }\end{array}$ & $1-\operatorname{FMR}(1-\mathrm{GF})$ \\
\hline & $\begin{array}{l}\text { vitrify/package removed } \\
\text { medium }\end{array}$ & $1-\mathrm{FMR}(1-\mathrm{VF})$ \\
\hline \multirow{5}{*}{$\begin{array}{l}\text { removal, treatment, and/or } \\
\text { remote disposal of treated } \\
\text { medium either off-site or in } \\
\text { alternative environmental } \\
\text { setting on-site }\end{array}$} & off-site disposal (on treatment) & 1 - FMR \\
\hline & $\begin{array}{l}\text { direct disposal in alternative } \\
\text { ES on-site }\end{array}$ & $1-\mathrm{FMR}(1-\mathrm{RF})$ \\
\hline & $\begin{array}{l}\text { treat to separate or destroy } \\
\text { contaminants \& replace in } \\
\text { alternative environmental } \\
\text { setting on-site }\end{array}$ & $1-\mathrm{FMR}[1-(\mathrm{FCR})(\mathrm{RF})]$ \\
\hline & $\begin{array}{l}\text { cement/package \& replace in } \\
\text { alternative environmental } \\
\text { setting on-site }\end{array}$ & $1-\mathrm{FMR}[1-(\mathrm{GF})(\mathrm{RF})]$ \\
\hline & $\begin{array}{l}\text { vitrify/package \& replace in } \\
\text { alternative environmental } \\
\text { setting on-site }\end{array}$ & $1-\mathrm{FMR}[1-(\mathrm{VF})(\mathrm{RF})]$ \\
\hline \multirow{4}{*}{$\begin{array}{l}\text { in situ treatment or } \\
\text { containment }\end{array}$} & in situ separation/destruction & FCR \\
\hline & grout in place & GF \\
\hline & in situ vitrification & VF \\
\hline & capping & $\mathrm{CF}$ \\
\hline \multirow{4}{*}{ ex situ waste treatment } & solidify liquid waste & SF \\
\hline & separate/destroy contaminants & FCR \\
\hline & cement solid waste & GF \\
\hline & vitrify solid waste & $\mathrm{VF}$ \\
\hline
\end{tabular}

FMR $=$ Fraction of contaminated Medium Removed for treatment

FCR $=$ Fraction of Contaminant Remaining (final concentration divided by initial concentration) after treatment to separate or destroy contaminant $\mathrm{GF}=$ Grout Factor $=$ (risk associated with unit of contaminant in grouted waste) $/($ risk associated with a unit contaminant in untreated waste)

$\mathrm{VF}=$ Vitrification Factor $=$ (risk associated with unit contaminant in vitrified waste)/(risk associated with a unit of contaminant in waste in original location) $\mathrm{RF}=$ Relocation Factor $=$ (risk associated with a unit of contaminant in relocated waste)/(risk associated with a unit of contaminant in waste in original location) $\mathrm{CF}=$ Capping Factor $=$ (risk associated with a unit of contaminant in waste after cap is applied)/(risk associated with a unit of contaminant in waste in original location prior to applying cap)

$\mathrm{SF}=$ Solidification Factor $=($ risk associated with unit of contaminant in solidified waste)/(risk associated with a unit of contaminant in liquid waste) 
Table 2.10 Contaminant Categories

\begin{tabular}{|c|c|c|c|c|c|c|}
\hline \multirow[b]{2}{*}{$\begin{array}{l}\text { contaminant } \\
\text { type }\end{array}$} & \multicolumn{3}{|c|}{ low mobility } & \multicolumn{3}{|c|}{ high mobility } \\
\hline & organic & $\begin{array}{l}\text { inorganic or } \\
\text { long half- } \\
\text { life } \\
\text { radionuclide }\end{array}$ & $\begin{array}{l}\text { short } \\
\text { half-life } \\
\text { radionuclide }\end{array}$ & organic & $\begin{array}{l}\text { inorganic or } \\
\text { long half-life } \\
\text { radionuclide }\end{array}$ & $\begin{array}{l}\text { short } \\
\text { half-life } \\
\text { radionuclide }\end{array}$ \\
\hline $\begin{array}{l}\text { representative } \\
\text { contaminant(s) }\end{array}$ & PCB & $\begin{array}{l}\text { mercury } \\
{ }^{239} \mathrm{Pu}\end{array}$ & ${ }^{137} \mathrm{Cs}$ & TCE & $\begin{array}{l}{ }_{99}^{\operatorname{arsenic}} \mathrm{Tc} \\
\end{array}$ & ${ }^{3} \mathrm{H}$ \\
\hline
\end{tabular}

\subsubsection{Illustrative HC Calculations}

The methodology described above was used to develop illustrative HCs for DOE sites, using site-specific information and data.

\subsection{Site-Specific Data and Information}

Illustrative hazard reduction factors, for use in calculating $\mathrm{HCs}$, were calculated for the following DOE installations and corresponding environmental settings:

$\underline{\text { DOE Installation }}$

Hanford

INEEL

Rocky Flats

Savannah River Plant

\section{Environmental Settings}

100-N Area

300 Area

200-E Area

ANL-W

CFA

Playas

TAN

RCWM

Coll_WmF

Coll_WIF

RFA_WmF

RFA_WIF

OU3

GS-TNX-D

$\mathrm{KC}$

$\mathrm{L}$

P-R

A-M 
Multiple "environmental settings" were analyzed for each DOE installation to reflect differences in major site characteristics (stratigraphy, hydrogeology, etc.) potentially affecting the transport of contaminants to receptors, and thereby affecting the risk calculation. These environmental settings are representative of the major areas of interest at these DOE installations. These environmental settings, and the corresponding data of interest were developed for analysis supporting DOE's Programmatic Environmental Impact Statement for Waste Management and DOE's Baseline Environmental Management Report (Holdren et al., 1995).

These data, as well as supplementary data were used to perform a set of RAAS analyses for each environmental setting (Buck et al., 1997). A "typical" waste site of 10 meters by 10 meters extending the entire depth of the top vadose zone layer was defined. Contaminant concentrations for all eight of the illustrative contaminants previously discussed were set at approximately $1 \%$ of the limiting concentration for each contaminant. (Characteristics of the soil such as porosity and moisture content, and characteristics of the contaminant such as its distribution coefficient $(\mathrm{Kd})$ and solubility limit the amount of contaminant that can be distributed uniformly in soil without accumulation of pure contamination.) The risk for a nearby receptor from contaminant transported via the groundwater pathway was then calculated by the RAAS methodology. The RAAS methodology reports either the estimated risk (e.g., $10^{-5}$ probability of incremental cancer incidence due to exposure to the contaminant from the waste site), or a lower limit of $10^{-10}$ if a lower-magnitude than that is calculated.

Similar risk calculations were performed assuming that the same waste site was capped, grouted in place, or vitrified in place. A fairly high performance cap was assumed (limiting infiltration to $1 \%$ of normal for 140 years). By accepting the default parameters in the RAAS methodology, typical grout diffusion coefficients and glass leach rates were used to represent grout in place and vitrify in place scenarios.

For each environmental setting, a contaminated pond or impoundment was also defined containing the same amount each contaminant as the corresponding soil waste site. The risk for a nearby receptor for contaminant transported from the pond via the groundwater pathway was then calculated by the RAAS methodology.

\subsection{Site-Specific Results}

Completing the calculations described above for all environmental settings at an installation allowed calculation of all the hazard reduction factors of interest for each environmental setting using the relationships previously described between the various risk calculation results.

Tables 2.11 through 2.14 show the results of these calculations for each environmental setting at each DOE installation. These tables do not contain estimates for the FMR and FCR factors. For the purpose of estimating HCs, either (1-FMR) or FCR can be roughly 
assumed to be in the range of $10^{-3}$ to $10^{-5}$, depending on the particular removal or treatment technology employed.

Also note that the results are shown only as "order of magnitude." The uncertainty implicit in risk estimation calculations makes reporting of additional significant figures misleading.

Table 2.11. Hanford Hazard Control Factor Parameters

\begin{tabular}{|c|c|c|c|c|c|c|c|}
\hline \multirow{4}{*}{$\begin{array}{l}\text { Environmental } \\
\text { Setting }\end{array}$} & \multirow{4}{*}{$\begin{array}{l}\text { Hazard } \\
\text { Reduction } \\
\text { Factor }\end{array}$} & \multicolumn{6}{|c|}{ Contaminant Type } \\
\hline & & \multicolumn{3}{|c|}{ Low mobility } & \multicolumn{3}{|c|}{ High mobility } \\
\hline & & Organic & $\begin{array}{l}\text { Inorganic or } \\
\text { long half- } \\
\text { life } \\
\text { radionuclide }\end{array}$ & $\begin{array}{l}\text { Short half- } \\
\text { life } \\
\text { radionuclide }\end{array}$ & Organic & $\begin{array}{l}\text { Inorganic or } \\
\text { long half- } \\
\text { life } \\
\text { radionuclide }\end{array}$ & $\begin{array}{l}\text { Short half- } \\
\text { life } \\
\text { radionuclide }\end{array}$ \\
\hline & & PCB & ${ }^{239} \mathrm{Pu}$ & ${ }^{137} \mathrm{Cs}$ & TCE & $\begin{array}{l}\text { Arsenic } \\
{ }_{99}^{99} \mathrm{Tc}\end{array}$ & ${ }^{3} \mathrm{H}$ \\
\hline \multirow{5}{*}{$100-N$ Area } & GF & 1 & 1 & 1 & 1 & 1 & $10^{-1}$ \\
\hline & $\mathrm{VF}$ & $<10^{-10}$ & 1 & $10^{-2}$ & $<10^{-10}$ & $10^{-3}$ & $10^{-5}$ \\
\hline & $\mathrm{RF}$ & 1 & 1 & $<10^{-10}$ & $10^{-1}$ & $<10^{-10}$ & $<10^{-10}$ \\
\hline & $\mathrm{CF}$ & 1 & 1 & 1 & 1 & 1 & $10^{-2}$ \\
\hline & SF & $10^{-5}$ & $10^{-1}$ & $<10^{-10}$ & 1 & 1 & 1 \\
\hline \multirow{5}{*}{300 Area } & GF & 1 & 1 & 1 & 1 & 1 & $10^{-1}$ \\
\hline & $\mathrm{VF}$ & $<10^{-10}$ & $10^{-1}$ & $10^{-3}$ & $<10^{-10}$ & $10^{-3}$ & $10^{-5}$ \\
\hline & $\mathrm{RF}$ & $10^{-2}$ & $10^{-8}$ & $<10^{-10}$ & 1 & $10^{-8}$ & $<10^{-10}$ \\
\hline & $\mathrm{CF}$ & 1 & 1 & 1 & 1 & 1 & $10^{-2}$ \\
\hline & SF & $10^{-3}$ & $10^{-1}$ & $10^{-3}$ & 1 & $10^{-1}$ & 1 \\
\hline \multirow{5}{*}{ 200-E Area } & GF & 1 & 1 & 1 & 1 & 1 & 1 \\
\hline & $\mathrm{VF}$ & 1 & 1 & 1 & 1 & 1 & 1 \\
\hline & $\mathrm{RF}$ & \multicolumn{6}{|c|}{$\begin{array}{l}\text { ENVIRONMENTAL SETTING ASSUMED FOR ALTERNATIVE } \\
\text { ON-SITE DISPOSAL SITE, RF }=1.0\end{array}$} \\
\hline & $\mathrm{CF}$ & 1 & \begin{tabular}{l|l} 
& 1 \\
\end{tabular} & \begin{tabular}{l|l} 
& 1
\end{tabular} & 1 & 1 & 1 \\
\hline & SF & $10^{-5}$ & $<10^{-10}$ & $<10^{-10}$ & 1 & $10^{-8}$ & $<10^{-10}$ \\
\hline
\end{tabular}


Table 2.12. INEEL Hazard Control Factor Parameters

\begin{tabular}{|c|c|c|c|c|c|c|c|}
\hline \multirow{4}{*}{$\begin{array}{l}\text { Environmental } \\
\text { Setting }\end{array}$} & \multirow{4}{*}{$\begin{array}{l}\text { Hazard } \\
\text { Reduction } \\
\text { Factor }\end{array}$} & \multicolumn{6}{|c|}{ Contaminant Type } \\
\hline & & \multicolumn{3}{|c|}{ Low mobility } & \multicolumn{3}{|c|}{ High mobility } \\
\hline & & Organic & $\begin{array}{l}\text { Inorganic or } \\
\text { long half- } \\
\text { life } \\
\text { radionuclide }\end{array}$ & $\begin{array}{l}\text { Short half- } \\
\text { life } \\
\text { radionuclide }\end{array}$ & Organic & $\begin{array}{l}\text { Inorganic or } \\
\text { long half- } \\
\text { life } \\
\text { radionuclide }\end{array}$ & $\begin{array}{l}\text { Short half- } \\
\text { life } \\
\text { radionuclide }\end{array}$ \\
\hline & & РCB & ${ }^{239} \mathrm{Pu}$ & ${ }^{137} \mathrm{Cs}$ & TCE & $\begin{array}{l}\text { Arsenic } \\
{ }^{99} \mathrm{Tc}\end{array}$ & ${ }^{3} \mathrm{H}$ \\
\hline \multirow{5}{*}{ ANL-W } & GF & 1 & 1 & 1 & 1 & 1 & 1 \\
\hline & $\mathrm{VF}$ & $<10^{-10}$ & 1 & 1 & $<10^{-10}$ & 1 & 1 \\
\hline & $\mathrm{RF}$ & 1 & 1 & 1 & $10^{-1}$ & 1 & 1 \\
\hline & $\mathrm{CF}$ & 1 & 1 & 1 & 1 & 1 & 1 \\
\hline & SF & $10^{-3}$ & $<10^{-10}$ & $<10^{-10}$ & $10^{-1}$ & $10^{-8}$ & $<10^{-10}$ \\
\hline \multirow{5}{*}{ CFA } & GF & 1 & 1 & 1 & 1 & 1 & 1 \\
\hline & $\mathrm{VF}$ & $<10^{-10}$ & 1 & 1 & $<10^{-10}$ & 1 & 1 \\
\hline & $\mathrm{RF}$ & 1 & 1 & 1 & $10^{-1}$ & 1 & 1 \\
\hline & $\mathrm{CF}$ & 1 & 1 & 1 & 1 & 1 & 1 \\
\hline & SF & 1 & $<10^{-10}$ & $10^{-6}$ & $10^{-1}$ & $<10^{-10}$ & $<10^{-10}$ \\
\hline \multirow{5}{*}{ Playas } & GF & 1 & 1 & 1 & 1 & 1 & 1 \\
\hline & $\mathrm{VF}$ & $<10^{-10}$ & 1 & 1 & $<10^{-10}$ & 1 & 1 \\
\hline & $\mathrm{RF}$ & 1 & 1 & 1 & $10^{-1}$ & 1 & $10^{-1}$ \\
\hline & $\mathrm{CF}$ & 1 & 1 & 1 & 1 & 1 & 1 \\
\hline & SF & 1 & 1 & 1 & $10^{-2}$ & $10^{-8}$ & $10^{-9}$ \\
\hline \multirow{5}{*}{ TAN } & GF & 1 & 1 & 1 & 1 & 1 & 1 \\
\hline & VF & $<10^{-10}$ & 1 & 1 & $<10^{-10}$ & 1 & 1 \\
\hline & $\mathrm{RF}$ & 1 & 1 & 1 & $10^{-1}$ & 1 & $10^{-1}$ \\
\hline & $\mathrm{CF}$ & 1 & 1 & 1 & 1 & 1 & 1 \\
\hline & SF & 1 & 1 & 1 & $10^{-2}$ & $10^{-8}$ & $<10^{-10}$ \\
\hline \multirow{5}{*}{ RCWM } & GF & 1 & 1 & 1 & 1 & 1 & 1 \\
\hline & VF & 1 & 1 & 1 & 1 & 1 & 1 \\
\hline & $\mathrm{RF}$ & \multicolumn{6}{|c|}{$\begin{array}{l}\text { ENVIRONMENTAL SETTING ASSUMED FOR ALTERNATIVE } \\
\text { ON-SITE DISPOSAL SITE, RF }=1.0\end{array}$} \\
\hline & $\mathrm{CF}$ & 1 & 1 & 1 & 1 & \begin{tabular}{l|l} 
& 1
\end{tabular} & 1 \\
\hline & SF & 1 & 1 & 1 & 1 & 1 & 1 \\
\hline
\end{tabular}


Table 2.13. Rocky Flats Hazard Control Factor Parameters

\begin{tabular}{|c|c|c|c|c|c|c|c|}
\hline \multirow{4}{*}{$\begin{array}{l}\text { Environmental } \\
\text { Setting }\end{array}$} & \multirow{4}{*}{$\begin{array}{l}\text { Hazard } \\
\text { Reduction } \\
\text { Factor }\end{array}$} & \multicolumn{6}{|c|}{ Contaminant Type } \\
\hline & & \multicolumn{3}{|c|}{ Low mobility } & \multicolumn{3}{|c|}{ High mobility } \\
\hline & & Organic & $\begin{array}{l}\text { Inorganic or } \\
\text { long half- } \\
\text { life } \\
\text { radionuclide }\end{array}$ & $\begin{array}{l}\text { Short half- } \\
\text { life } \\
\text { radionuclide }\end{array}$ & Organic & $\begin{array}{l}\text { Inorganic or } \\
\text { long half- } \\
\text { life } \\
\text { radionuclide }\end{array}$ & $\begin{array}{l}\text { Short half- } \\
\text { life } \\
\text { radionuclide }\end{array}$ \\
\hline & & PCB & ${ }^{239} \mathrm{Pu}$ & ${ }^{137} \mathrm{Cs}$ & TCE & $\begin{array}{l}\text { Arsenic } \\
{ }^{99} \mathrm{Tc}\end{array}$ & ${ }^{3} \mathrm{H}$ \\
\hline \multirow{5}{*}{ Coll_WmF } & GF & 1 & 1 & 1 & 1 & 1 & 1 \\
\hline & VF & $<10^{-10}$ & 1 & $10^{-1}$ & $<10^{-10}$ & $10^{-2}$ & $10^{-4}$ \\
\hline & $\mathrm{RF}$ & $10^{-1}$ & $10^{-1}$ & $10^{-1}$ & $10^{-1}$ & $10^{-1}$ & $10^{-1}$ \\
\hline & $\mathrm{CF}$ & 1 & 1 & $10^{-1}$ & 1 & 1 & $10^{-2}$ \\
\hline & SF & $10^{-1}$ & $10^{-1}$ & $10^{-1}$ & 1 & 1 & 1 \\
\hline \multirow{5}{*}{ Coll_WIF } & GF & 1 & 1 & 1 & 1 & 1 & 1 \\
\hline & VF & $<10^{-10}$ & 1 & $10^{-1}$ & $<10^{-10}$ & $10^{-2}$ & $10^{-4}$ \\
\hline & $\mathrm{RF}$ & $10^{-1}$ & $10^{-1}$ & $10^{-1}$ & $10^{-1}$ & $10^{-1}$ & $10^{-1}$ \\
\hline & $\mathrm{CF}$ & 1 & 1 & $10^{-1}$ & 1 & 1 & $10^{-2}$ \\
\hline & $\mathrm{SF}$ & $10^{-1}$ & $10^{-1}$ & $10^{-1}$ & 1 & 1 & 1 \\
\hline \multirow{5}{*}{ RFA_WmF } & GF & 1 & 1 & 1 & 1 & 1 & 1 \\
\hline & VF & $<10^{-10}$ & $10^{-1}$ & 1 & $<10^{-10}$ & $10^{-2}$ & $10^{-4}$ \\
\hline & RF & 1 & 1 & $10^{-1}$ & $10^{-1}$ & $10^{-1}$ & $10^{-1}$ \\
\hline & $\mathrm{CF}$ & 1 & 1 & $10^{-1}$ & 1 & 1 & $10^{-1}$ \\
\hline & SF & 1 & 1 & 1 & 1 & 1 & 1 \\
\hline \multirow{5}{*}{ RFA_WIF } & GF & 1 & 1 & 1 & 1 & 1 & 1 \\
\hline & VF & $<10^{-10}$ & $10^{-1}$ & 1 & $<10^{-10}$ & $10^{-2}$ & $10^{-4}$ \\
\hline & $\mathrm{RF}$ & 1 & 1 & $10^{-1}$ & $10^{-1}$ & $10^{-1}$ & $10^{-1}$ \\
\hline & $\mathrm{CF}$ & 1 & 1 & $10^{-1}$ & 1 & 1 & $10^{-1}$ \\
\hline & SF & 1 & 1 & 1 & 1 & 1 & 1 \\
\hline \multirow{5}{*}{ OU3 } & GF & 1 & 1 & 1 & 1 & 1 & 1 \\
\hline & VF & $<10^{-10}$ & $10^{-1}$ & 1 & $<10^{-10}$ & $10^{-2}$ & $10^{-4}$ \\
\hline & $\mathrm{RF}$ & \multicolumn{6}{|c|}{$\begin{array}{l}\text { ENVIRONMENTAL SETTING ASSUMED FOR ALTERNATIVE } \\
\text { ON-SITE DISPOSAL SITE, RF }=1.0\end{array}$} \\
\hline & $\mathrm{CF}$ & 1 & \begin{tabular}{l|l} 
& 1
\end{tabular} & $10^{-1}$ & \begin{tabular}{l|l} 
& 1
\end{tabular} & \begin{tabular}{l|l} 
& 1
\end{tabular} & \begin{tabular}{l|l} 
& $10^{-1}$
\end{tabular} \\
\hline & SF & $10^{-2}$ & $10^{-2}$ & $10^{-1}$ & 1 & $10^{-2}$ & $10^{-1}$ \\
\hline
\end{tabular}


Table 2.14. Savannah River Hazard Control Factor Parameters

\begin{tabular}{|c|c|c|c|c|c|c|c|}
\hline \multirow{4}{*}{$\begin{array}{l}\text { Environmental } \\
\text { Setting }\end{array}$} & \multirow{4}{*}{$\begin{array}{l}\text { Hazard } \\
\text { Reduction } \\
\text { Factor }\end{array}$} & \multicolumn{6}{|c|}{ Contaminant Type } \\
\hline & & \multicolumn{3}{|c|}{ Low mobility } & \multicolumn{3}{|c|}{ High mobility } \\
\hline & & Organic & $\begin{array}{l}\text { Inorganic or } \\
\text { long half- } \\
\text { life } \\
\text { radionuclide }\end{array}$ & $\begin{array}{l}\text { Short half- } \\
\text { life } \\
\text { radionuclide }\end{array}$ & Organic & $\begin{array}{l}\text { Inorganic or } \\
\text { long half- } \\
\text { life } \\
\text { radionuclide }\end{array}$ & $\begin{array}{l}\text { Short half- } \\
\text { life } \\
\text { radionuclide }\end{array}$ \\
\hline & & РCB & $\begin{array}{l}\text { Mercury } \\
{ }^{239} \mathrm{Pu}\end{array}$ & ${ }^{137} \mathrm{Cs}$ & TCE & $\begin{array}{l}\text { Arsenic } \\
{ }_{99}^{99} \mathrm{Tc}\end{array}$ & ${ }^{3} \mathrm{H}$ \\
\hline \multirow{5}{*}{ GS-TNX-D } & GF & 1 & 1 & 1 & 1 & 1 & $10^{-1}$ \\
\hline & $\mathrm{VF}$ & $<10^{-10}$ & $10^{-2}$ & $10^{-2}$ & $<10^{-10}$ & $10^{-4}$ & $10^{-6}$ \\
\hline & $\mathrm{RF}$ & 1 & $10^{-2}$ & $10^{-2}$ & $10^{-2}$ & $10^{-2}$ & $10^{-2}$ \\
\hline & $\mathrm{CF}$ & 1 & 1 & 1 & 1 & 1 & $10^{-2}$ \\
\hline & SF & 1 & 1 & 1 & 1 & 1 & 1 \\
\hline \multirow{5}{*}{ KC } & GF & 1 & 1 & 1 & 1 & 1 & $10^{-1}$ \\
\hline & $\mathrm{VF}$ & $<10^{-10}$ & $10^{-2}$ & $10^{-3}$ & $<10^{-10}$ & $10^{-4}$ & $10^{-6}$ \\
\hline & $\mathrm{RF}$ & 1 & $10^{-1}$ & $10^{-2}$ & $10^{-2}$ & $10^{-2}$ & $10^{-2}$ \\
\hline & $\mathrm{CF}$ & 1 & 1 & 1 & 1 & 1 & $10^{-2}$ \\
\hline & SF & 1 & 1 & 1 & 1 & 1 & 1 \\
\hline \multirow{5}{*}{$\mathrm{L}$} & GF & 1 & 1 & 1 & 1 & 1 & $10^{-1}$ \\
\hline & $\mathrm{VF}$ & $<10^{-10}$ & $10^{-2}$ & $10^{-3}$ & $<10^{-10}$ & $10^{-4}$ & $10^{-6}$ \\
\hline & $\mathrm{RF}$ & 1 & $10^{-1}$ & $10^{-2}$ & $10^{-2}$ & $10^{-2}$ & $10^{-2}$ \\
\hline & $\mathrm{CF}$ & 1 & 1 & 1 & 1 & 1 & $10^{-2}$ \\
\hline & SF & 1 & 1 & 1 & 1 & 1 & 1 \\
\hline \multirow{5}{*}{ P-R } & GF & 1 & 1 & 1 & 1 & 1 & $10^{-1}$ \\
\hline & $\mathrm{VF}$ & $<10^{-10}$ & $10^{-2}$ & $10^{-3}$ & $<10^{-10}$ & $10^{-4}$ & $10^{-6}$ \\
\hline & $\mathrm{RF}$ & 1 & $10^{-2}$ & $10^{-2}$ & $10^{-2}$ & $10^{-2}$ & $10^{-2}$ \\
\hline & $\mathrm{CF}$ & 1 & 1 & 1 & 1 & 1 & $10^{-2}$ \\
\hline & SF & 1 & 1 & 1 & 1 & 1 & 1 \\
\hline \multirow{5}{*}{ A-M } & GF & 1 & 1 & 1 & 1 & 1 & $10^{-1}$ \\
\hline & $\mathrm{VF}$ & $<10^{-10}$ & $10^{-1}$ & 1 & $<10^{-10}$ & $10^{-2}$ & $10^{-4}$ \\
\hline & $\mathrm{RF}$ & \multicolumn{6}{|c|}{$\begin{array}{l}\text { ENVIRONMENTAL SETTING ASSUMED FOR ALTERNATIVE } \\
\text { ON-SITE DISPOSAL SITE, RF }=1.0\end{array}$} \\
\hline & $\mathrm{CF}$ & 1 & 1 & 1 & 1 & \begin{tabular}{l|l} 
& 1
\end{tabular} & $10^{-2}$ \\
\hline & $\mathrm{SF}$ & $10^{-2}$ & $10^{-2}$ & $10^{-2}$ & 1 & $10^{-5}$ & $10^{-1}$ \\
\hline
\end{tabular}




\subsection{Approach to Calculating Relative Hazard Ratios Using the RH Equation}

In using the $\mathrm{RH}$ equation to estimate $\mathrm{RH}$ ratios and produce relative hazard reduction graphs, one should always apply the test of "technical feasibility and reasonableness" to each factor of the equation and to the final resulting $\mathrm{RH}$ value generated over the course of the projected risk management actions. In most cases, it will be helpful to either mentally and/or physically sketch out an intuitive $\mathrm{RH}$ graph considering all the risk management actions being considered. Then, once the RH calculations are made, a comparison of the resulting graph with the intuitive graph can be made to test the reasonableness of the results. Any significant discrepancies should be examined by looking at the individual parameters and the logic behind them.

The general steps of the RH estimation methodology include:

- Using the site specific "Current Risk/Hazards" and "Future Risk/Hazard Management Actions" tables of the site's risk profile, determine the controlling constituents, quantities (considering total amounts and releasable fractions of controlling constituents), controlling pathways, and risk management actions pertinent to the waste type being evaluated.

- Assigning site specific values, for the base case and each risk/hazard management action case, to the parameters of the $\mathrm{RH}$ equation, using data from the risk profile tables, site specific risk assessment data, values from look-up tables, and general knowledge of the site in question.

- Assigning quantity $(\mathrm{Q})$ and release fraction $(\mathrm{RF})$ values for the controlling constituents; if values of $Q$ are all releasable to the controlling pathway, the respective RF value can be assigned a 1 .

- Assigning hazard measure (HM) values (specific for the controlling constituent and pathway), using the HM look-up tables provided. As the overall risk management approach is examined, consider the logic flow where a specific risk/hazard management activity may cause a change from one pathway to another or a change in the status of the controlling constituent (e.g., a separations and disposal process where the initial controlling constituent is either changed or eliminated resulting in a different controlling constituent)

- Assigning hazard control (HC) values (specific for each risk/hazard management activity). In many cases, the hazard control is simply related to the reduction in the volume (i.e., amount of controlling constituents) of the hazardous material in question. In these cases, simply assign the $\mathrm{HC}$ value a 1 and adjust the $\mathrm{Q}$ values over time to reflect the reduction or use the FMR and /or FCR factors, as applicable to generate an $\mathrm{HC}$ value to account for the volume change. The HC values are intended to reflect significant impact changes in the waste material or its setting (e.g., vitrification of the same amount of waste to change its form, repackaging leaking hazardous material, moving hazardous material away from a vulnerable exposure setting). In some cases, there will be both reduction in 
volume and changes in the waste material or setting, so a representative $\mathrm{HC}$ value should be used along with a reduction in the $\mathrm{Q}$ values (or the appropriate FMR and/or FCR factors of the HC used to account for the volume change). If risk assessment results are available for the general activity or a related activity at the site, use the results of the risk assessment to estimate the order of magnitude worth of the activity. If no pertinent risk assessment results are available, use the HC look-up tables provided to estimate the worth of the activity. Use these table values in combinations with the Q and HM parameters to as closely as possible represent the logic flow of all the risk management activities at the site.

- Assemble all of the RH equation factor values, with references and assumption information documented, into a simple worksheet format to provide documentation for the analysis process.

- Calculate the RH ratio values, considering the general flow of activities that occur over time. As mentioned, it would be helpful to either mentally or physically sketch out an intuitive graph of the activities over time. These sketches will prove invaluable in selecting the best $\mathrm{RH}$ equation input factors and assure the results are logically reasonable.

- Assign "best estimate" relative time (RT) values based on the general understanding of time associated with the completion of each risk/hazard management activity. In many cases, quantity and activity data are presented on a year by year basis, which is the best data for an RH graph. In these cases, simply assign RT values by year. In cases, where these year by year data are not available, it will be necessary to estimate the number of years out from the starting time that each risk/hazard management activity is projected to occur and the amount of time that it will take to complete the activity. Then, assign these time blocks to the respective RT values.

- Develop a plotting table, using the plotting routine software of your choice, and produce the individual waste type RH versus RT plots. For purposes of the risk profiles, use only order of magnitude axes scaling (listing of axis values is optional), label the axes, and write the pertinent risk/hazard management action identifier information directly on the graphs. In past risk profile development, several sites have asked not to have the axis values presented, because they can easily get misinterpreted as absolute risk values (i.e., order of magnitude risk values). This problem was solved in past risk profiles by simply including tick marks and noting in the text (and/or as footnotes) that each tick mark represents an order of magnitude reduction in the relative hazard. 


\subsection{Relative Hazard Application Examples}

Example RH calculations and graphs are provided in the following sections to help the reader to see how the method can be applied to actual site examples and how flexible application of the method can be in meeting the data availability constraints and the needs of a site's specific risk story. Two example cases, with considerably different levels of available input data, are shown to illustrate the flexibility of the methodology. Close examination of the RH equations, as presented in the examples, shows that the methodology tends to single out the specific risk (hazard) management factor(s) that are being altered by the projected risk management actions. The methodology has the flexibility to adjust as many of the factors in the RH equation as is necessary to best represent the hazard reduction effected by the projected risk management activity at a site.

\subsection{Example Site \#1}

The Example Site \#1 provides a good example of a site with known declining (decaying) inventory over time. Each time increment is a 10 -year period. Also, the site has a large volume of waste containing some relatively short half-life material that will naturally decline over the years. For simplification purposes the site inventory was divided into either surface or sub-surface inventory categories. The inventory information is presented in Tables EXMP1-1 (Sub-Surface Inventory) and EXMP1-2 (Surface Inventory) [inventory amounts are in curies].

\section{Calculation Notes:}

\section{$\underline{\text { Surface Contamination }}$}

The GW pathway is assumed to be the controlling pathway.

The total initial inventory associated with surface contamination, as taken from Table EXMP1-2, is $2042 \mathrm{Ci}$. Thus,

Q total $=2042 \mathrm{Ci}$.

The baseline disposition maps show an $8 \%$ reduction in this inventory associated with treatment and offsite disposal (i.e., $168 \mathrm{Ci}$ ); a $0.9 \%$ reduction due to offsite disposal (i.e. $18 \mathrm{Ci}$ ); and a $0.4 \%$ reduction due to continued onsite controls (i.e., $8 \mathrm{Ci}$ ). The treatment and onsite disposal activities need to consider decay as a means of reducing the inventory of radionuclides. This reduction in inventory is shown in Table EXMP1-2 (i.e., 2042 initial inventory and 1300 decayed inventory for the 70 year period shown). Thus,

Q treatment \& offsite disposal $=168 \mathrm{Ci}$;

Q offsite disposal $=18 \mathrm{Ci}$;

$\mathrm{Q}$ continued onsite control = 8 Ci (part of current operations);

$\mathrm{Q}$ treatment $\&$ onsite disposal $=2042 \mathrm{Ci}$; Q w/decay over $70 \mathrm{yr}=1300 \mathrm{Ci}$. 
It was assumed that all of the inventory was releasable to the environment. Thus,

$\mathrm{RF}=1$.

The plutonium isotopes were considered to be the controlling constituents for the analysis. Using the HM look-up table for the groundwater pathway, an HM value of 10 was assigned. Thus,

$\mathrm{HM}=10$.

A hazard control factor of one (1) is assigned to current operations, because this is assumed to be the baseline for which to compare the reductions. Based on the disposition maps, the site estimated the fraction of media removed (i.e., FMR) from the amount associated with treatment \& offsite hazardous disposal (i.e., the $168 \mathrm{Ci}$ ) is roughly $12 \%$ (i.e., FMR = 0.12). Based on past experience and assessments, the site estimated that their treatment and onsite disposal operations effected roughly four orders of magnitude reduction in risk. This four orders of magnitude reduction was assumed to be associated with controlling the hazard; thus, an $\mathrm{HC}$ value of E-4 was assigned to the treatment and onsite disposal operations. Thus,

$\mathrm{HC}$ current operations $=1$

$\mathrm{HC}$ treatment \& offsite hazardous disposal $=(1-\mathrm{FMR})=(1-0.12)=0.88$

$\mathrm{HC}$ treatment \& onsite disposal = E-4

Applying the above factors to the RH equation, results in the following $\mathrm{RH}$ values for the various risk/hazard management actions projected for the site:

RH current operations $=(2042 / 2042)(1 / 1)(10 / 10)(1 / 1)]=1$

RH treatment \& offsite haz. mtrl. disposal $=(168 / 2042)(10 / 10)(0.88 / 1)=0.07$

RH treatment \& onsite disposal w/o decay $=(2042 / 2042)(10 / 10)(\mathrm{E}-4 / 1)=1.0 \mathrm{E}-4$

$\mathrm{RH}$ treatment $\&$ onsite disposal w/decay $=(1300 / 2042)(10 / 10)(\mathrm{E}-4 / 1)=6.4 \mathrm{E}-5$

The risk profile tables show that the remediation of offsite surface contamination is scheduled to begin in 2006; thus, an RT period of from 0.0 to 7.0 was assigned to current operations. It was estimated that the treatment \& offsite hazardous material disposal operations will take roughly three (3) years; thus, and RT value of 10 was assigned to this action. The analysis was performed for a 70-year period; thus, an RT value was assigned to the treatment \& onsite disposal w/decay operations. The treatment \& onsite disposal w/o decay RH calculation was provided above simply to examine the effect of the decay. The following plot table was produced:

$\underline{\mathrm{RT}} \quad \underline{\mathrm{RH}}$

$\overline{0.00} \quad \overline{1.00}$

$7.00 \quad 1.00$

$10.00 \quad 0.07$

$70.00 \quad 6 \mathrm{E}-5$ 


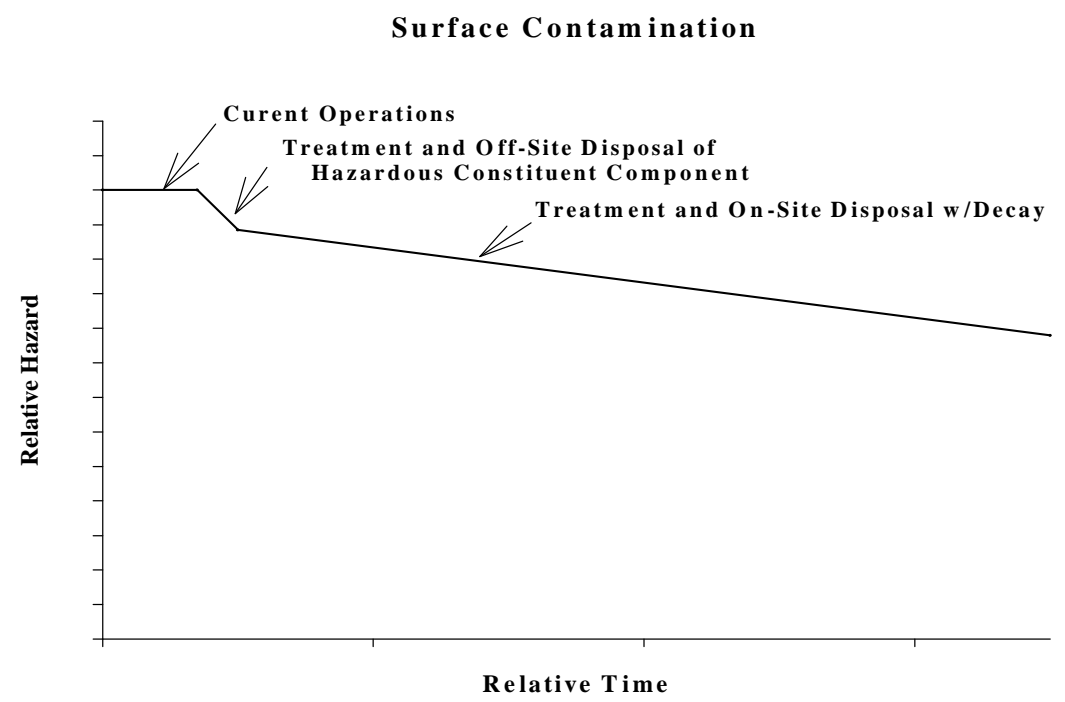

\section{$\underline{\text { Sub-Surface Contamination }}$}

The GW pathway is assumed to be the controlling pathway.

The total initial inventory associated with sub-surface contamination, as taken from Table EXMP1-1, is 1.1E8 Ci. Thus,

Q subsurface contamination $=1.1 \mathrm{E} 8 \mathrm{Ci}$.

Based on information provided in Table EXMP1-1, decay results in a 70-year inventory of 4.1E6 Ci. Thus,

Q subsurface contamination $\mathrm{w} / 70 \mathrm{yr}$ decay $=4.1 \mathrm{E} 6 \mathrm{Ci}$.

It was assumed that all of the inventory was releasable to the environment. Thus,

$\mathrm{RF}=1.0$

The Cs-137 isotope was considered to be the controlling constituent. It had the highest activity fraction, next to tritium, and it also had the highest associated HM factor (1000) from the groundwater table. Thus,

$\mathrm{HM}=1000$.

A robust groundwater monitoring and control program is cited in the risk profile table for the risk management action for sub-surface contamination. While such a program is 
essential to safely maintain the sub-surface contamination, it does not reduce the hazard. Thus,

HC maintain institutional control $=1$

Applying the above factors to the RH equation, results in the following $\mathrm{RH}$ values for sub-surface contamination risk/hazard management at the site:

$\mathrm{RH}$ current operations $=(1.1 \mathrm{E} 8 / 1.1 \mathrm{E} 8)(1000 / 1000)(1 / 1)=1$

$\mathrm{RH}$ monitoring \& management $\mathrm{w} / 70 \mathrm{yr}$ decay $=(4.1 \mathrm{E} 6 / 1.1 \mathrm{E} 8)(1000 / 1000)(1 / 1)=3.7 \mathrm{E}-2$

The risk profile table projects the continuance of administrative control with robust groundwater monitoring for the entire 70-year period; thus, the RT values, as presented in the following plot table, apply:

Plot Table:

$\underline{\mathrm{RT}} \quad \underline{\mathrm{RH}}$

$0.00 \quad 1.00$

$70.0 \quad 4 \mathrm{E}-2$

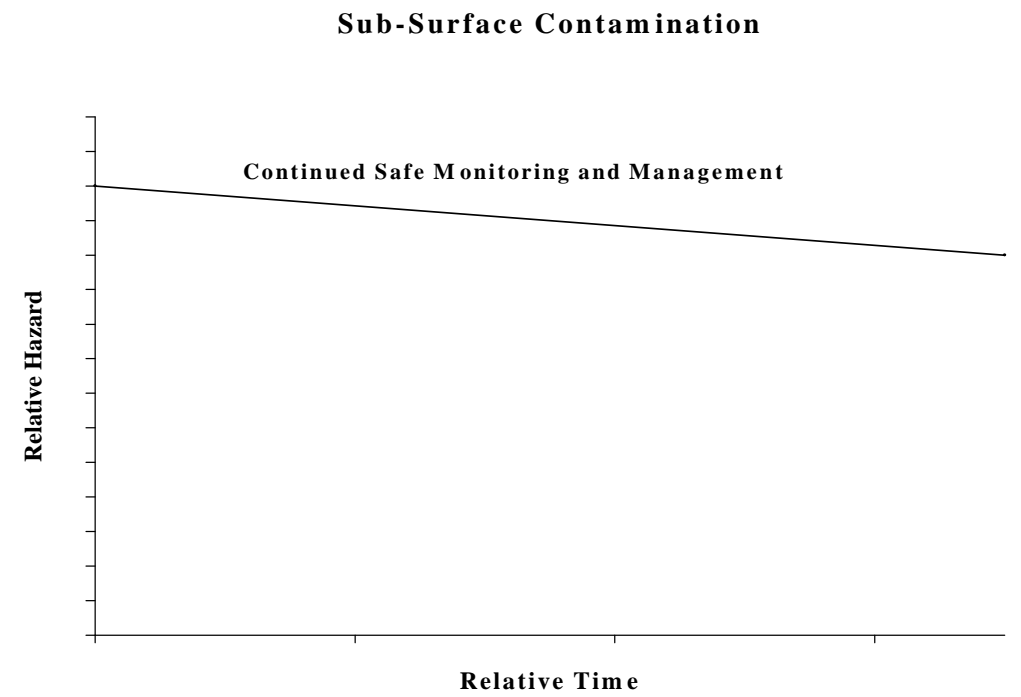




\section{$\underline{\text { Waste Disposal Operations }}$}

The following inventory information for waste disposal operations was received from the site:

$500,000 \mathrm{Ci}$ landfills w/surface isotopic distribution

$1,250 \mathrm{Ci}$ crater subsidence $\mathrm{w} /$ surface isotopic distribution

$\underline{9,000,000} \mathrm{Ci}$ underground $\mathrm{w} / 89 \%$ tritium \& $7.3 \%$ americium assumed

9,502,250 Ci total; thus,

$\mathrm{Q}$ current total $\approx 1 \mathrm{E}+7 \mathrm{Ci}$.

The estimated surface isotopic distribution is: C0-60 (1.7\%), Sr-90 (16.1\%), Cs-137 (15.1\%), Eu-152 (7.2\%), Pu-239 (52.4\%), and Am-241 (7.3\%).

For the landfills and crater subsidence, a surface isotopic distribution is to be assumed. The surface distribution percentage can be obtained from Table EXMP1-2. The reduction in the mixture (i.e., the landfills \& crater subsidence materials) due to 70 years of decay can then be estimated from the initial and 70-year totals of the table [i.e., 1 $1.3 \mathrm{E} 3 / 2042=1.0-0.64=0.36]$. The tritium decay can be estimated as $98.1 \%$ over the 70-year period using the data in Table EXMP1-1 [i.e., (1.01E8 - 1.95E6)/1.01E8 = 98.1\%]. The americium decay can be estimated as $13.3 \%$ over the 70 -year period using the data in Table EXMP1-2 [i.e., $(150-130) / 150=13.3 \%$ ]. This all results in the following decay corrections with resulting 70-year decayed inventory:

$\mathrm{Q} 70 \mathrm{mix}=501,250 \mathrm{Ci}(0.36)=\quad 180,450 \mathrm{Ci}$

Q $70 \mathrm{H}-3=9,000,000 \mathrm{Ci}(0.89)(1-0.981)=152,190 \mathrm{Ci}$

Q $70 \mathrm{Am}-241=9,000,000(0.07)(1-0.133)=\underline{546,210} \mathrm{Ci}$

$$
\text { Total } \approx 9 \mathrm{E} 5 \mathrm{Ci} \text {. }
$$

The AM-241 isotope was considered to be the controlling constituent for the analysis, since it makes up the largest amount of the decayed inventory after the 70-year period (i.e., 546,210 Ci) and has a long half-life. From the HM look-up table for groundwater, Am-241 has an HM value of 1,000. Thus,

$\mathrm{HM}=1000$.

Given the isolation, climate, depth-to-groundwater, cover, containment, monitoring and management of the disposed waste, the site has estimated the worth of the control actions to be roughly four orders of magnitude. Thus,

$\mathrm{HC}$ covering and confinement $=\mathrm{E}-4$

Applying the above factors to the RH equation, results in the following $\mathrm{RH}$ values for the risk/hazard management actions projected for waste disposal operations: 
RH current $=(9.5 \mathrm{E} 6 / 9.5 \mathrm{E} 6)(1000 / 1000)(1 / 1)=1$

RH waste receipt, covering \& confinement $=(9.5 \mathrm{E} 6 / 9.5 \mathrm{E} 6)(1000 / 1000)(\mathrm{E}-4 / 1)=1.0 \mathrm{E}-4$

RH covering, confinement, $\&$ decay $=(8.8 \mathrm{E} 5 / 9.5 \mathrm{E} 6)(1000 / 1000)(\mathrm{E}-4 / 1)=9.3 \mathrm{E}-6$

The risk profile tables show current operations continuing for roughly 8 years with waste receipt, covering and confinement operations occurring over a 40 year period. Decay was applied over the 70-year analysis period. These time assumptions result in the RT values presented in the following plot table:

$\underline{\mathrm{RT}} \quad \underline{\mathrm{RH}}$

$0.00 \quad 1.00$

$8.00 \quad 1.00$

$40.00 \quad 1 \mathrm{E}-4$

$70.0 \quad 9 \mathrm{E}-6$

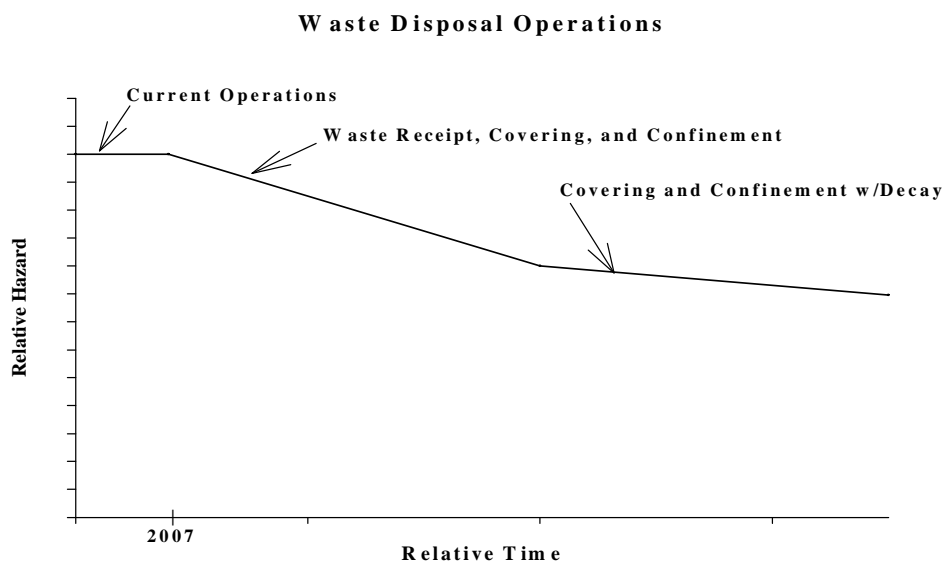

\section{$\underline{\text { References }}$}

Since the purpose of this analysis is only to serve as an example, the pertinent references are not included; however, documenting the references is an important part of an actual analysis. In past analyses, the inventory information was assembled in a spreadsheet utilizing the reference note capability of the spreadsheet software. This allows specific documentation of the references from which each specific piece of information/data was obtained. It is also good practice to include a bibliographic list of all the references (cited in the spreadsheet) in the calculation notes. 
Table EXMP1-1. Sub-Surface Inventory

\begin{tabular}{|c|c|c|c|c|c|c|c|c|c|c|c|c|c|c|c|c|}
\hline Rad & $\begin{array}{l}\text { Initial } \\
\text { Inv. }\end{array}$ & $\begin{array}{l}\text { Act. } \\
\text { Frac. }\end{array}$ & $\begin{array}{l}10 y \\
\text { Inv. }\end{array}$ & $\begin{array}{l}\text { Act. } \\
\text { Frac }\end{array}$ & $\begin{array}{l}20 y \\
\text { Inv. }\end{array}$ & $\begin{array}{l}\text { Act. } \\
\text { Frac }\end{array}$ & $\begin{array}{l}\text { 30y } \\
\text { Inv. }\end{array}$ & $\begin{array}{l}\text { Act. } \\
\text { Frac }\end{array}$ & $\begin{array}{l}40 y \\
\text { Inv. }\end{array}$ & $\begin{array}{l}\text { Act. } \\
\text { Frac }\end{array}$ & $\begin{array}{l}50 y \\
\text { Inv. }\end{array}$ & $\begin{array}{l}\text { Act. } \\
\text { Frac }\end{array}$ & $\begin{array}{l}60 y \\
\text { Inv. }\end{array}$ & $\begin{array}{l}\text { Act. } \\
\text { Frac }\end{array}$ & $\begin{array}{l}70 y \\
\text { Inv. }\end{array}$ & $\begin{array}{l}\text { Act. } \\
\text { Frac }\end{array}$ \\
\hline $\mathrm{H}-3$ & $1.0 \mathrm{E} 8$ & 0.901 & $5.7 \mathrm{E} 7$ & 0.869 & $3.3 \mathrm{E} 7$ & 0.828 & $1.9 \mathrm{E} 7$ & 0.777 & $1.1 \mathrm{E} 7$ & 0.715 & $6.0 \mathrm{E} 6$ & 0.643 & $3.4 \mathrm{E} 6$ & 0.564 & $2.0 \mathrm{E} 6$ & 0.481 \\
\hline $\mathrm{Kr}-85$ & 3.7E5 & 0.003 & $1.9 \mathrm{E} 5$ & 0.003 & $1.0 \mathrm{E} 5$ & 0.003 & $5.3 \mathrm{E} 4$ & 0.002 & $2.8 \mathrm{E} 4$ & 0.002 & $1.5 \mathrm{E} 4$ & 0.002 & $7.6 \mathrm{E} 3$ & 0.001 & $4.0 \mathrm{E} 3$ & 0.001 \\
\hline Sr-90 & 4.7E6 & 0.042 & $3.7 \mathrm{E} 6$ & 0.055 & 2.9E6 & 0.073 & 2.3E6 & 0.094 & $1.8 \mathrm{E} 6$ & 0.119 & $1.4 \mathrm{E} 6$ & 0.147 & $1.1 \mathrm{E} 6$ & 0.178 & $8.5 \mathrm{E} 5$ & 0.209 \\
\hline Cs-137 & $5.7 \mathrm{E} 6$ & 0.051 & $4.5 \mathrm{E} 6$ & 0.068 & $3.6 \mathrm{E} 6$ & 0.091 & 2.9E6 & 0.119 & $2.3 \mathrm{E} 6$ & 0.153 & $1.8 \mathrm{E} 6$ & 0.192 & $1.4 \mathrm{E} 6$ & 0.235 & $1.1 \mathrm{E} 6$ & 0.280 \\
\hline $\begin{array}{l}\text { Sm- } \\
151\end{array}$ & $1.9 \mathrm{E} 5$ & 0.002 & $1.8 \mathrm{E} 5$ & 0.003 & $1.6 \mathrm{E} 5$ & 0.004 & $1.5 \mathrm{E} 5$ & 0.006 & $1.4 \mathrm{E} 5$ & 0.009 & $1.3 \mathrm{E} 5$ & 0.014 & $1.2 \mathrm{E} 5$ & 0.020 & $1.1 \mathrm{E} 5$ & 0.027 \\
\hline $\mathrm{Pu}-241$ & $1.9 \mathrm{E} 5$ & 0.002 & $1.2 \mathrm{E} 5$ & 0.002 & 7.3E4 & 0.002 & $4.5 \mathrm{E} 4$ & 0.002 & $2.8 \mathrm{E} 4$ & 0.002 & $1.7 \mathrm{E} 4$ & 0.002 & $1.1 \mathrm{E} 4$ & 0.002 & $6.6 \mathrm{E} 3$ & 0.002 \\
\hline Total & $1.1 \mathrm{E} 8$ & 1.000 & $6.6 \mathrm{E} 7$ & 1.000 & $4.0 \mathrm{E} 7$ & 1.000 & $2.4 \mathrm{E} 7$ & 1.000 & $1.5 \mathrm{E} 7$ & 1.000 & 9.4E6 & 1.000 & $6.1 \mathrm{E} 6$ & 1.000 & 4.1E6 & 1.000 \\
\hline
\end{tabular}

Table EXMP1-2 Surface Inventory

\begin{tabular}{|c|c|c|c|c|c|c|c|}
\hline Rad & T $1 / 2(d)$ & $\begin{array}{l}\text { Initial Inv. } \\
\text { (Ci) }\end{array}$ & Initial \% & $\begin{array}{l}\text { Frac. Of N } 25550 \\
\text { (t,days) }\end{array}$ & 70 yr. Inv. (Ci) & $\%$ at 70 yr. & $\begin{array}{l}\text { \% Reduction } \\
\text { In Total }\end{array}$ \\
\hline Co-60 & $1.92 \mathrm{E} 3$ & 35 & 1.71 & $9.9 \mathrm{E}-5$ & $3.5 \mathrm{E}-3$ & 0.0 & 10 \\
\hline Sr-90 & $1.04 \mathrm{E} 4$ & 330 & 16.16 & $1.8 \mathrm{E}-1$ & $6.0 \mathrm{E} 1$ & 4.5 & 81.8 \\
\hline Cs-137 & $1.10 \mathrm{E} 4$ & 310 & 15.18 & $2.0 \mathrm{E}-1$ & $6.2 \mathrm{E} 1$ & 4.7 & 80 \\
\hline Eu-152 & $4.96 \mathrm{E} 3$ & 147 & 7.20 & $2.8 \mathrm{E}-2$ & 4.1 & 0.3 & 97.2 \\
\hline $\mathrm{Pu}-239$ & 8.81E6 & 1070 & 52.40 & 1.0 & $1.1 \mathrm{E} 3$ & 80.4 & 2.8 \\
\hline Am-241 & $1.58 \mathrm{E} 5$ & 150 & 7.35 & 8.9E-1 & $1.3 \mathrm{E} 2$ & 10.1 & 13.3 \\
\hline Total & & 2042 & 100.00 & & $1.3 \mathrm{E} 3$ & 100.00 & 36.3 \\
\hline
\end{tabular}




\subsection{Example Site \#2}

The Example Site \#2 analysis provides a good example of a site with detailed annual source term quantity data, but for security reasons, detailed curie content data were not releasable for all waste types at the site. Thus, the volume data were used in the analysis. These data are less desirable for the analysis, because the results will be less comparable across the different waste types. It also necessitates assigning the entire volume of the material to the controlling constituent(s) quantity. This generally produces an overly conservative quantity of the respective constituent(s). However, since the $\mathrm{RH}$ is a ratio these quantities will balance out for most cases. A case where this overly conservative approach could greatly impact the relative hazard results is where risk management actions involve direct modification to part or all of the inventory (e.g, separation, elimination or reduction of controlling constituents in the total inventory).

\section{Calculation Notes:}

The inventories were taken from the site's disposition maps. Specific waste streams within a waste type were consolidated in an effort to roll up the inventories to the highest level that matched the PBS descriptions. HC factors were based on risk evaluations conducted for a site-specific cumulative impact assessment.

\section{$\underline{\text { Nuclear Materials }}$}

The air pathway is assumed to be the controlling pathway.

The initial inventory is the sum of the inventories presented for nuclear materials in the risk profile tables, divided into the categories of solids/sludges and liquids. Thus,

$\mathrm{Q}=1.3 \mathrm{E} 4 \mathrm{Kg}$ solids and sludges

$\mathrm{Q}=1.2 \mathrm{E} 2 \mathrm{Kg}$ liquids

It was assumed that all of the inventory was releasable to the environment. Thus,

$\mathrm{RF}=1.0$.

The plutonium and uranium isotopes were considered to be the controlling constituents for the analysis. Using the HM look-up table for the air pathway, an HM value of 1.0E4 was assigned. Thus,

$\mathrm{HM}=1.0 \mathrm{E} 4$

Based on an internal risk assessment for the site, the site submitted the following $\mathrm{HC}$ values to be considered for the projected risk/hazard management actions:

HC current $=1$ (baseline) 
$\mathrm{HC}$ solid residue stabilize \& repack $=1.8$ (reflects increase in inventory activity)

$\mathrm{HC}$ pits removed from site $=0.4$

$\mathrm{HC}$ snm consolidated $=0.1$

$\mathrm{HC}$ enriched uranium removed from site $=0.05$

$\mathrm{HC}$ liquid residue stabilization $=0.01$

HC Pu metal \& oxides stabilized, repacked \& shipped offsite $=0.005$

$\mathrm{HC}$ solid residue stabilized, repacked $\&$ shipped offsite $=0.001$

Applying the above factors to the RH equation, results in the following $\mathrm{RH}$ values for the various risk/hazard management actions projected for the site:

RH current solid \& sludge $=(1.3 \mathrm{E} 4 / 1.3 \mathrm{E} 4)(1 / 1)(1.0 \mathrm{E} 4 / 1.0 \mathrm{E} 4)(1 / 1)=1$

RH current liquid $=(1.2 \mathrm{E} 2 / 1.2 \mathrm{E} 2)(1 / 1)(1.0 \mathrm{E} 4 / 1.0 \mathrm{E} 4)(1 / 1)=1$

RH solid residue stabilize \& repack $=(1.3 \mathrm{E} 4 / 1.3 \mathrm{E} 4)(1 / 1)(1.8 / 1)=1.8$

RH pits removed from site $(1.3 \mathrm{E} 4 / 1.3 \mathrm{E} 4)(1 / 1)(1.0 \mathrm{E} 4 / 1.0 \mathrm{E} 4)(0.4 / 1)=0.4$

RH snm consolidated $=(1.3 \mathrm{E} 4 / 1.3 \mathrm{E} 4)(1 / 1)(1.0 \mathrm{E} 4 / 1.0 \mathrm{E} 4)(0.01 / 1)=0.01$

RH enriched $\mathrm{u}$ removed from site $=(1.3 \mathrm{E} 4 / 1.3 \mathrm{E} 4)(1 / 1)(1.0 \mathrm{E} 4 / 1.0 \mathrm{E} 4)(0.05 / 1)=0.05$

RH liquid residue stabilization $=(1.2 \mathrm{E} 2 / 1.2 \mathrm{E} 2)(1 / 1)(1.0 \mathrm{E} 4 / 1.0 \mathrm{E} 4)(0.1 / 1)=0.1$

RH Pu metal \& oxides stabilized, repacked, and shipped offsite $=(1.3 \mathrm{E} 4 / 1.3 \mathrm{E} 4)(1 / 1)$

RH solid residue stabilized, repacked \& shipped offsite $=(1.3 \mathrm{E} 4 / 1.3 \mathrm{E} 4)(1 / 1)$

$(1.0 \mathrm{E} 4 / 1.0 \mathrm{E} 4)(0.005 / 1)=0.005$

$$
(1.0 \mathrm{E} 4 / 1.0 \mathrm{E} 4)\left(0.001 / 1_{-}=0.001\right.
$$

Only a 20 year analysis period was used, because the site is schedule to be cleaned up within that period of time. The site provided specific dates for completion of the various risk/hazard management activities, which were converted directly, by starting from a 1998 starting point, into the RT values shown in the following plot table:

$\begin{array}{lc}\frac{\mathrm{RT}}{0.00} & \underline{\mathrm{RH}} \\ 1.00 & 1.00 \\ 1.50 & 1.00 \\ 1.55 & 1.80 \\ 1.70 & 0.40 \\ 3.50 & 0.10 \\ 7.00 & 5.00 \mathrm{E}-2 \\ 7.80 & 1.00 \mathrm{E}-2 \\ 20.00 & 5.00 \mathrm{E}-3 \\ & 1.00 \mathrm{E}-3\end{array}$




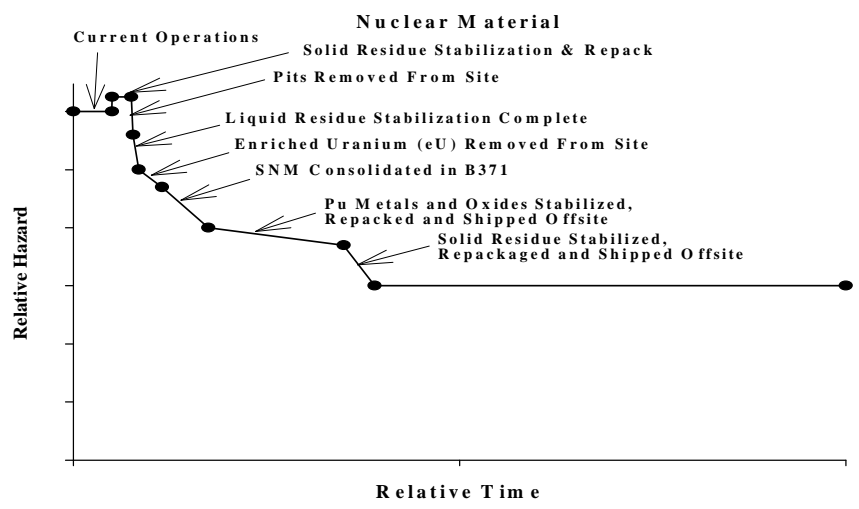

$\underline{\text { Transuranic (TRU) Waste }}$

The air pathway is assumed to be the controlling pathway.

The total inventory is the sum of the inventories presented for transuranic waste in the risk profile tables. Thus,

$\mathrm{Q}=9.5 \mathrm{E} 3 \mathrm{~m}^{3}$.

The site provide the following year by year inventory projections through the year 2009, with running $Q$ values assigned accordingly, which included each years increase:

$\underline{\text { Year }} \quad \underline{\text { Additional Inventory }\left(\mathrm{m}^{3}\right)}$

1998

126

$1999-1000$

$2000 \quad 2000$

20012000

$2002 \quad 2000$

$2003 \quad 1774$

$2004 \quad 344$

$2005 \quad 157$

$2006 \quad 64$

$2007 \quad 45$

$2008 \quad 14$

$2009 \quad 9$

Total $9.5 \mathrm{E} 3$ 
It was assumed that all of the inventory was releasable to the environment. Thus,

$\mathrm{RF}=1$.

The plutonium isotopes were considered to be the controlling constituents for the analysis. Using the HM look-up table for the air pathway, an HM value of 1.0E4 was assigned. Thus,

$\mathrm{HM}=1.0 \mathrm{E} 4$.

Based on an internal risk assessment for the site, the site submitted the following HC values to be considered for the projected risk/hazard management actions:

HC current $=1$ (baseline)

$\mathrm{HC}$ during residue stabilization \& D\&D activities $=1$ (actual increases in RH due to generation, shown as inventory increase)

$\mathrm{HC}$ residue stabilization $\& \mathrm{D} \& \mathrm{D}$ complete $=0.0001$

Applying the above factors to the RH equation, results in the following RH values for the various risk/hazard management actions projected for the site:

RH current $=(126 / 126)(1 / 1)(1.0 \mathrm{E} 4 / 1.0 \mathrm{E} 4)(1 / 1)=1$

RH $99=[(126+1000) / 126](1 / 1)(1.0 \mathrm{E} 4 / 1.0 \mathrm{E} 4)((1 / 1)=8.9$

RH $2000=[(126+1000+2000) / 126](1 / 1)(1.0 \mathrm{E} 4 / 1.0 \mathrm{E} 4)(1 / 1)=24.8$

RH $2001=[(126+1000+2000+2000) / 126](1 / 1)(1.0 \mathrm{E} 4 / 1.0 \mathrm{E} 4)(1 / 1)=40.7$

RH $2002=[(126+1000+2000+2000+2000) / 126](1 / 1)(1.0 \mathrm{E} 4 / 1.0 \mathrm{E} 4)(1 / 1)=56.6$

RH $2003=[(126+1000+6000+1774) / 126](1 / 1)(1.0 \mathrm{E} 4 / 1.0 \mathrm{E} 4)(1 / 1)=70.6$

RH $2004=[(126+1000+6000+1774+344) / 126](1 / 1)(1.0 \mathrm{E} 4 / 1.0 \mathrm{E} 4)(1 / 1)=73.3$

RH $2005=[(126+1000+6000+1774+344+157) / 126](1 / 1)(1.0 \mathrm{E} 4 / 1.0 \mathrm{E} 4)(1 / 1)=74.6$

RH $2006=[(126+1000+6000+1774+344+157+64) / 126](1 / 1)(1.0 \mathrm{E} 4 / 1.0 \mathrm{E} 4)(1 / 1)=75.1$

RH $2007=[(126+1000+6000+1774+344+157+64+45) / 126](1 / 1)(1.0 \mathrm{E} 4 / 1.0 \mathrm{E} 4)(1 / 1)$ $=75.5$

RH $2008=[(126+1000+6000+1774+344+157+64+45+14) / 126](1 / 1)(1.0 \mathrm{E} 4 / 1.0 \mathrm{E} 4)(1 / 1)$ $=75.6$

RH $2009=[(126+1000+6000+1774+344+157+64+45+14+9) / 126](1 / 1)(1.0 \mathrm{E} 4 / 1.0 \mathrm{E} 4)$ $(1 / 1)=75.63$

$\mathrm{RH}$ residue stabilization \& D\&D complete $=(9533 / 126)(1 / 1)(1.0 \mathrm{E} 4 / 1.0 \mathrm{E} 4)(0.0001 / 1)$

$$
=7.5 \mathrm{E}-3
$$

Only a 20 year analysis period was used, because the site is scheduled to be cleaned up within that period of time. The individual years associated with each inventory change were used to directly assign RT values resulting in the following plot table: 


$\begin{array}{lc}\underline{\mathrm{RT}} & \underline{\mathrm{RH}} \\ 0.00 & 1.00 \\ 1.00 & 1.00 \\ 2.00 & 8.90 \\ 3.00 & 24.80 \\ 4.00 & 40.70 \\ 5.00 & 56.60 \\ 6.00 & 70.60 \\ 7.00 & 73.30 \\ 8.00 & 74.60 \\ 9.00 & 75.10 \\ 10.00 & 75.50 \\ 11.00 & 75.60 \\ 12.00 & 75.63 \\ 16.0 & 0.0075 \\ 20.0 & 0.0075\end{array}$

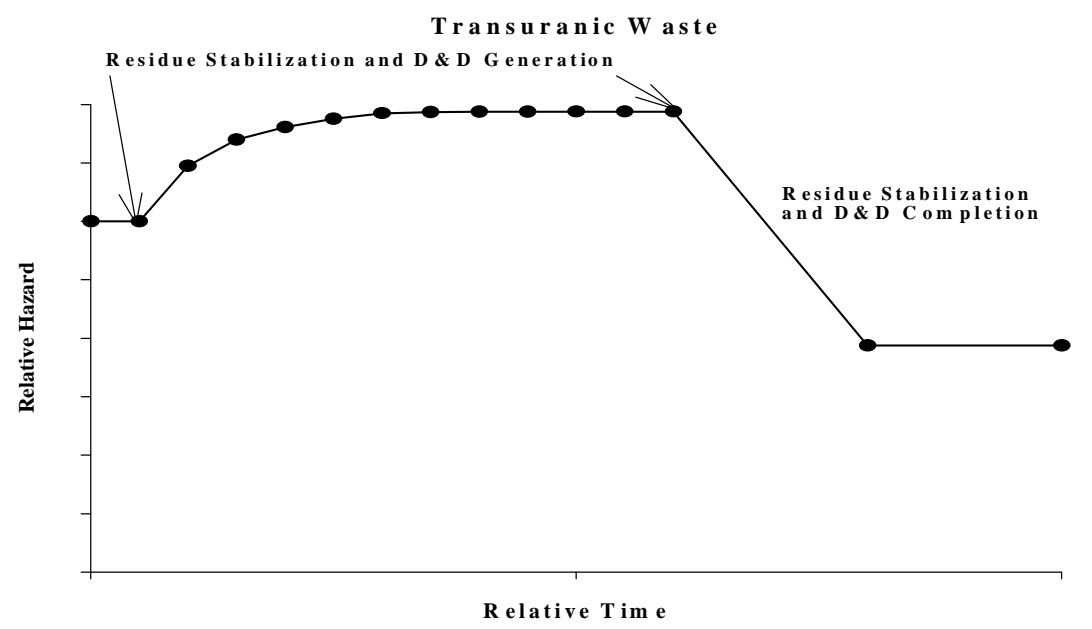

Low Level Waste (LLW) and Low Level Mixed Waste (LLMW)

The surface water pathway is assumed to be the controlling pathway.

The total inventory is the sum of the inventories presented for low level waste (LLW) and mixed low level waste (MLLW) in the risk profile tables. Thus,

$\mathrm{Q}=3.5 \mathrm{E} 5 \mathrm{~m}^{3}$. 
The site provide the following year by year inventory projections through the year 2020, with $\mathrm{Q}$ values for each year assigned accordingly:

\begin{tabular}{|c|c|}
\hline Year & Inventory $\left(\mathrm{m}^{3}\right)$ \\
\hline 1998 & 7118 \\
\hline 1999 & 9250 \\
\hline 2000 & 6800 \\
\hline 2001 & 18899 \\
\hline 2002 & 12635 \\
\hline 2003 & 13149 \\
\hline 2004 & 14043 \\
\hline 2005 & 13309 \\
\hline 2006 & 12647 \\
\hline 2007 & 12234 \\
\hline 2008 & 12224 \\
\hline 2009 & 11977 \\
\hline 2010 & 11977 \\
\hline 2020 & $\underline{11977}$ \\
\hline & $3.5 \mathrm{E} 5$ \\
\hline
\end{tabular}

It was assumed that all of the inventory was releasable to the environment. Thus,

$\mathrm{RF}=1$.

The plutonium and uranium isotopes were considered to be the controlling constituents for the analysis. Using the HM look-up table for the surface water pathway, an HM value of $1.0 \mathrm{E} 3$ was assigned. Thus,

$\mathrm{HM}=1.0 \mathrm{E} 3(\mathrm{Pu} \& \mathrm{U}$ isotopes, $100 \mathrm{nCi} / \mathrm{g}$ controlling constituents)

Based on an internal risk assessment for the site, the site submitted the following HC values to be considered for the projected risk/hazard management actions:

HC current $=1$ (baseline)

$\mathrm{HC} \mathrm{d} \& \mathrm{~d}$ completion $=1.0 \mathrm{E}-3$

Applying the above factors to the RH equation, results in the following $\mathrm{RH}$ values for the risk/hazard management actions projected for the site:

RH current $1998=(7118 / 7118)(1 / 1)(1.0 \mathrm{E} 3 / 1.0 \mathrm{E} 3)(1 / 1)=1$

RH $1999=(9250 / 7118)(1 / 1)(1.0 \mathrm{E} 3 / 1.0 \mathrm{E} 3)(1 / 1)=1.3$

RH $2000=(6800 / 7118)(1 / 1)(1.0 \mathrm{E} 3 / 1.0 \mathrm{E} 3)(1 / 1)=0.96$

RH $2001=(18899 / 7118)(1 / 1)(1.0 \mathrm{E} 3 / 1.0 \mathrm{E} 3)(1 / 1)=2.65$

RH $2002=(12635 / 7118)(1 / 1)(1.0 \mathrm{E} 3 / 1.0 \mathrm{E} 3)(1 / 1)=1.77$ 


$$
\begin{aligned}
& \text { RH } 2003=(13149 / 7118)(1 / 1)(1.0 \mathrm{e} 3 / 1.0 \mathrm{E} 3)(1 / 1)=1.84 \\
& \text { RH } 2004=(14043 / 7118)(1 / 1)(1.0 \mathrm{E} 3 / 1.0 \mathrm{E} 3)(1 / 1)=1.97 \\
& \text { RH } 2005=(13309 / 7118)(1 / 1)(1.0 \mathrm{E} 3 / 1.0 \mathrm{E} 3)(1 / 1)=1.87 \\
& \text { RH 2006 }=(12647 / 7118)(1 / 1)(1 / 0 \mathrm{E} 3 / 1.0 \mathrm{E} 3)(1 / 1)=1.77 \\
& \text { RH } 2007=(12234 / 7118)(1 / 1)(1.0 \mathrm{E} 3 / 1.0 \mathrm{E} 3)(1 / 1)=1.71 \\
& \text { RH 2008 }=(12224 / 7118)(1 / 1)(1.0 \mathrm{E} 3 / 1.0 \mathrm{E} 3)(1 / 1)=1.71 \\
& \text { RH 2009 }=(11977 / 7118)(1 / 1)(1.0 \mathrm{E} 3 / 1.0 \mathrm{E} 3)(1 / 1)=1.69 \\
& \text { RH 2010 }=(11977 / 7118)(1 / 1)(1.0 \mathrm{E} 3 / 1.0 \mathrm{E} 3)(1.0 \mathrm{E}-3 / 1)=1.69 \mathrm{E}-3 \\
& \text { RH 2020 }=(11977 / 7118)(1 / 1)(1.0 \mathrm{E} 3 / 1.0 \mathrm{E} 3)(1.0 \mathrm{E}-3 / 1)=1.69 \mathrm{E}-3
\end{aligned}
$$

Only a 20 year analysis period was used, because the site is scheduled to be cleaned up within that period of time. The individual years associated with each inventory were used to directly assign RT values resulting in the following plot table:

$\begin{array}{lc}\frac{\mathrm{RT}}{0.00} & \underline{\mathrm{RH}} \\ 1.00 & 1.00 \\ 2.00 & 1.00 \\ 3.00 & 1.30 \\ 4.00 & 0.96 \\ 5.00 & 2.65 \\ 6.00 & 1.77 \\ 7.00 & 1.84 \\ 8.00 & 1.97 \\ 9.00 & 1.87 \\ 10.00 & 1.77 \\ 11.00 & 1.71 \\ 12.00 & 1.71 \\ 13.0 & 1.69 \\ 23.0 & 1.69 \mathrm{e}-3 \\ & 1.69 \mathrm{e}-3\end{array}$

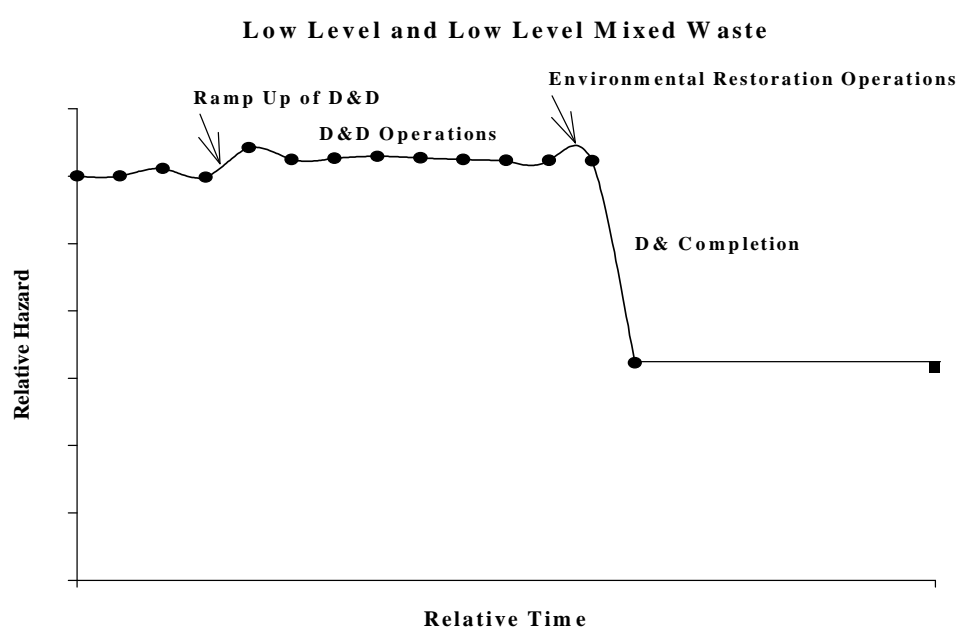




\subsection{Risk Measure (RM) Calculation}

The relative hazard factor tracks the change in hazard over time. Another important consideration is the change in risk for the facility. As mentioned previously, the relative risk is related to the relative hazard by the frequency of a release event for the facility. A risk measure (RM) can be calculated in a manner similar to the relative hazard factor by addition of the hazard likelihood (HL) to the relative hazard equation. The hazard likelihood is represented as the expected frequency of the event that results in release of a contaminant to the environment. This can be represented by the following equation.

$$
R R=\frac{\sum_{s=1}^{S} \sum_{c c=1}^{N} H L_{c c t s} Q_{c c t s} R F_{c c c t s} H M_{c c t} H C_{c c t s}}{\sum_{s=1}^{S} \sum_{c c=1}^{N} Q_{c c t 0 s} R F_{c c t 0} H M_{c c t 0} H C_{c c t 0 s}}
$$

Where,

$$
\begin{aligned}
& \mathrm{RM}=\text { risk measure at time } \mathrm{t} \text { (per year) } \\
& \mathrm{HL}_{\text {ccts }}=\text { likelihood that a release will occur for the controlling constituents } \\
& \text { at time } t \text { for scenario s (i.e., time when specified risk management } \\
& \text { action is completed) } \\
& \text { Qccts = quantity of the controlling constituents (radionuclides, in curies } \\
& \text { and hazardous chemicals, in kilograms) at time } t \text { for scenario } s \\
& \mathrm{Q}_{\mathrm{cct} 0 \mathrm{~s}}=\text { quantity of the controlling constituents (radionuclides, in curies } \\
& \text { and hazardous chemicals, in kilograms) at time t0 for scenario } \mathrm{s} \\
& \mathrm{RF}_{\text {ccts }}=\text { fraction of controlling constituent quantity that is releasable to } \\
& \text { the controlling pathway at time } t \text { for scenario } s \\
& \mathrm{RF}_{\text {ct0s }}=\text { fraction of the controlling constituent quantity that is releasable to } \\
& \text { the controlling pathway at time } t 0 \text { for scenario } s \\
& \mathrm{HM}_{\mathrm{cct}}=\text { hazard measure factor for controlling constituent and controlling } \\
& \text { pathway at time } t \text { (hazard measure factors from look-up tables) } \\
& \mathrm{HM}_{\mathrm{cct} 0}=\text { hazard measure factor for controlling constituent and controlling } \\
& \text { pathway at time to (hazard measure factors from look-up tables) } \\
& \mathrm{HC}_{\text {ccts }}=\text { hazard control factor for risk management control action specific at } \\
& \text { time } t \text { for scenario s (hazard control factors may be estimated from } \\
& \text { site risk data or approximated using supplied look-up tables) } \\
& \mathrm{HC}_{\mathrm{cct} 0 \mathrm{~s}}=\text { hazard control factor for risk management control action specific at } \\
& \text { time } \mathrm{t} 0 \text { for scenario } \mathrm{s} \text { (hazard control factors may be estimated } \\
& \text { from site risk data or approximated using supplied look-up tables) } \\
& \mathrm{N}=\text { number of controlling constituents } \\
& \mathrm{S}=\text { number of controlling events (accident scenarios) for the analysis }
\end{aligned}
$$

Most of these terms (other than the hazard likelihood) are defined and evaluated the same as for the Relative Hazard evaluation described in Section 2. These terms are not addressed in this section. Note that the hazard likelihood is only added to the numerator of the relative hazard equation. This allows the risk measure to be compared to the relative hazard values and plotted as a function of time. 
The equation includes the number of controlling events (scenarios) that may result in significant releases of the controlling constituents. For some facilities, there may be only one controlling event, while for others, there may be multiple events that need to be included. As improvements are made to facilities and operations, the likelihood of an event is expect to decrease. As the likelihood of one event is reduced there may or may not be a corresponding change in the likelihood of another event. This could lead to one event dominating the risk measure initially, and a second event dominating at a later time.

The summation over controlling events may be used to represent multiple events for processing of one hazardous material, or to represent more than one hazardous material. In the latter case, each hazardous material would have one or more events defined for evaluation of the risk measure.

\subsection{Hazard Likelihood (HL) Factor}

The hazard likelihood factor is related to the frequency of an event that results in release of material or otherwise results in impacts to the public or workers. Guidance is given in this section on evaluation of the event frequencies.

The HL factor represents the likelihood (or frequency) that a release will occur for a controlling event and for the controlling constituent. This factor can be thought of as the probability or frequency of a specific accident that results in a release. The frequency is usually expressed on an annual basis (e.g., events/year). The frequency is defined for the event that is most likely to release the controlling constituent in the largest amount. When there are multiple events postulated that release the controlling constituent, the analysis may need to include more that one event. In cases where actions are defined to reduce the $\mathrm{RM}$, the analyst should be aware of alternate events that may become dominant when the initially dominant event is mitigated by protective actions that do not mitigate the alternate event frequencies.

The assignment of accident frequencies must be based on knowledge of the facility and processes. This may include the use of knowledgeable staff in assigning frequencies, or reliance on safety analysis reports or other similar reports for the facility. Fischer et al. 1996 describe use of Quantitative Hazard Analysis to assist in the design and development phase of a project to improve system safety. The method relies on experts to define accident sequences and frequencies. The risk assessment handbook for Rocky Flats safety analysis (RFETS 1997) describes a method for performing safety analysis for nuclear facilities at Rocky Flats. The handbook describes a methodological approach to assess the potential hazards for a facility and prepare necessary documentation of the risks (SAR, BIO or BFO). The method relies on use of staff familiar with the facility and processes. The Rocky Flats handbook provides a table of frequency bin designations for use in accident analyses. These designations are listed in Table 4.1 with suggested midrange values. 
Table 4.1. Suggested Frequency Bin Designations

\begin{tabular}{|l|c|c|}
\hline Frequency Category & $\begin{array}{c}\text { Frequency Range } \\
\text { (events/year) }\end{array}$ & $\begin{array}{c}\text { Midrange Value } \\
\text { (events/year) }\end{array}$ \\
\hline Normal operations & $>1.0$ & 1.0 \\
\hline Expected or anticipated & 0.01 to 1.0 & 0.1 \\
\hline Unlikely & $1 \mathrm{E}-4$ to $1 \mathrm{E}-2$ & $1 \mathrm{E}-3$ \\
\hline Extremely unlikely & $1 \mathrm{E}-6$ to $1 \mathrm{E}-4$ & $1 \mathrm{E}-5$ \\
\hline Incredible & $<1 \mathrm{E}-6$ & $1 \mathrm{E}-7$ \\
\hline
\end{tabular}

In the past few years, the DOE has investigated the state of the DOE complex holdings on spent fuel, chemicals, plutonium, and highly-enriched uranium in an attempt to identify materials and conditions that pose a threat to health and safety for workers or the public. The plutonium vulnerability study (DOE 1994) and the highly-enriched uranium vulnerability study (DOE 1996) both employed a simplified consequence analysis method to estimate the potential for adverse health impacts. This analysis method was applied to each "vulnerability" identified for each DOE site and facility included in the study.

Vulnerabilities were classified according to type, likelihood, and consequences. The vulnerability type classification was either material packaging (MP), facility condition (FC), or institutional (IV). These classifications are intended to indicate the primary cause for the vulnerability. Material packaging classification is used for vulnerabilities that involve susceptibility of materials and packaging to degradation from design deficiencies, corrosion, radiolytic damage, or changes in chemical form. Facility condition classification is used for vulnerabilities involving potential for failure of physical barriers such as equipment, building, or safety systems, and the hold-up of plutonium or uranium in a facility (e.g. ductwork). Institutional vulnerabilities involve administrative or management weaknesses that are underlying causes of or significant contributors to, material/packaging and facility condition vulnerabilities. The likelihood categories employed in each of these studies are indicated in Table 4.2. 
Table 4.2. Likelihood Categories used in the Vulnerability Studies

\begin{tabular}{|l|l|l|}
\hline Category & $\begin{array}{l}\text { HEU Vulnerability } \\
\text { Study }\end{array}$ & $\begin{array}{l}\text { Pu Vulnerability } \\
\text { Study }\end{array}$ \\
\hline Very Low & $\begin{array}{l}<0.02, \text { less than once in } \\
\text { 50 years }\end{array}$ & $\begin{array}{l}\text { NPH (very small } \\
\text { frequency expected) }\end{array}$ \\
\hline Low & $\begin{array}{l}0.02-0.2, \text { once in } 5-50 \\
\text { years }\end{array}$ & $\begin{array}{l}0.02-0.2, \text { once in 5 } \\
-50 \text { years }\end{array}$ \\
\hline Medium & - & $\begin{array}{l}0.2-0.5, \text { once in 2 - } \\
5 \text { years }\end{array}$ \\
\hline High & $>0.2$, within 5 years & $>0.5$, within 2 years \\
\hline
\end{tabular}

The very low category was typically applied to events resulting from natural phenomena (e.g. seismic events) and is consistent with the incredible to unlikely categories given in Table 4.1-1. The low and medium categories are within the expected or anticipated categories. And the high approaches the normal operations range. The vulnerability studies were primarily interested in the problems most likely to occur and cause health or environmental impacts.

The vulnerability summary tables for these studies have been reviewed and the vulnerabilities have been grouped by cause, event, and likelihood in Table 4.3 and 4.4 for the plutonium and highly-enriched uranium studies, respectively. The tables include most vulnerabilities, but exclude the institutional vulnerabilities which were not assigned frequency categories by the vulnerability studies.

A few generalizations can be made from the information in these tables. Events resulting from human error are in the "expected or anticipated" frequency category. Poor packaging of plutonium or uranium is likely to result in "expected or anticipated" frequency category events. Seismic events are related to the "unlikely" category. Events involving contamination (rooms, ducts, equipment, etc.) are in the "expected or anticipated" frequency category. 
Table 4.3 Likelihood Summary for Plutonium Vulnerability Study

\begin{tabular}{|c|c|c|c|c|c|}
\hline \multirow{3}{*}{ Cause } & \multirow{3}{*}{ Event } & \multicolumn{4}{|c|}{ Likelihood Category } \\
\hline & & $\begin{array}{c}\mathrm{VL} \\
<<0.02\end{array}$ & $\begin{array}{c}\mathrm{L} \\
0.02- \\
0.2\end{array}$ & $\begin{array}{c}\mathrm{M} \\
0.2- \\
0.5\end{array}$ & $\begin{array}{l}\mathrm{H} \\
\mathrm{H}\end{array}$ \\
\hline & & \multicolumn{4}{|c|}{ Number of Vulnerabilities } \\
\hline \multirow{4}{*}{$\begin{array}{l}\text { human error or } \\
\text { equipment failure }\end{array}$} & building fire & - & 7 & 1 & - \\
\hline & breach of facility & - & 9 & 12 & 10 \\
\hline & criticality & - & 3 & 1 & - \\
\hline & worker exposure & - & 2 & 2 & - \\
\hline $\begin{array}{l}\text { long-term plutonium } \\
\text { solution storage in } \\
\text { plastic bottles }\end{array}$ & leakage/spill & - & - & - & 7 \\
\hline \multirow{3}{*}{$\begin{array}{l}\text { material package } \\
\text { physical condition }\end{array}$} & container breach & - & 10 & 10 & 18 \\
\hline & material fire & - & - & 1 & 6 \\
\hline & solution spill & - & 1 & 2 & 1 \\
\hline $\begin{array}{l}\text { Plutonium metal or } \\
\text { oxides stored in } \\
\text { contact with plastic } \\
\text { or oxidation }\end{array}$ & container breach & - & 9 & 5 & 1 \\
\hline \multirow[t]{2}{*}{ internal explosion } & $\begin{array}{l}\text { release inside } \\
\text { building }\end{array}$ & - & 2 & - & - \\
\hline & breach of facility & - & 7 & - & - \\
\hline $\begin{array}{l}\text { inadequacy of } \\
\text { criticality safety } \\
\text { limits }\end{array}$ & criticality & - & 5 & - & - \\
\hline \multirow[t]{3}{*}{ Seismic event } & criticality & 1 & 4 & - & - \\
\hline & material fire & 1 & 1 & - & - \\
\hline & breach of facility & 16 & - & - & - \\
\hline Aircraft crash & breach of facility & 1 & 3 & - & - \\
\hline Extreme winds & breach of facility & 1 & - & - & - \\
\hline $\begin{array}{l}\text { Contaminated } \\
\text { rooms or equipment }\end{array}$ & release & - & 14 & 4 & 11 \\
\hline $\begin{array}{l}\text { unnecessary } \\
\text { combustible } \\
\text { material }\end{array}$ & fire or explosions & - & 3 & 1 & - \\
\hline
\end{tabular}


Table 4.4 Likelihood Summary for the Highly-Enriched Uranium Vulnerability Study

\begin{tabular}{|c|c|c|c|c|}
\hline \multirow[t]{3}{*}{ Cause } & \multirow[t]{3}{*}{ Event } & \multicolumn{3}{|c|}{ Likelihood Category } \\
\hline & & $\begin{array}{c}\mathrm{VL} \\
<<0.02\end{array}$ & $\begin{array}{c}\mathrm{L} \\
0.02- \\
0.2\end{array}$ & $\begin{array}{c}\mathrm{H} \\
>0.2\end{array}$ \\
\hline & & \multicolumn{3}{|c|}{ Number of Vulnerabilities } \\
\hline \multirow{3}{*}{$\begin{array}{l}\text { human error or } \\
\text { equipment failure }\end{array}$} & building fire & - & 3 & - \\
\hline & breach of facility & 3 & 1 & 4 \\
\hline & worker exposure & - & 2 & 2 \\
\hline \multirow[t]{4}{*}{ Facility deficiency } & release & 4 & 5 & 6 \\
\hline & criticality & 1 & 2 & - \\
\hline & worker exposure & - & 1 & 1 \\
\hline & fire & - & 3 & - \\
\hline \multirow{4}{*}{$\begin{array}{l}\text { inadequate storage, } \\
\text { material package } \\
\text { physical condition }\end{array}$} & container breach & - & 5 & 6 \\
\hline & criticality & 1 & 4 & - \\
\hline & worker exposure & - & 2 & 1 \\
\hline & solution spill & - & 1 & - \\
\hline $\begin{array}{l}\text { HEU with } \\
\text { Plutonium in } \\
\text { contact with plastic }\end{array}$ & release & - & 1 & - \\
\hline $\begin{array}{l}\text { Pyrophoric metal } \\
\text { chip storage }\end{array}$ & Fire & 3 & 3 & - \\
\hline $\begin{array}{l}\text { chemical reaction, } \\
\text { explosion }\end{array}$ & breach of facility & 1 & 3 & - \\
\hline \multirow[t]{3}{*}{ Seismic event } & criticality & 3 & - & - \\
\hline & spill & 1 & - & - \\
\hline & breach of facility & 10 & 1 & - \\
\hline Winds & breach of facility & 4 & 1 & - \\
\hline $\begin{array}{l}\text { Transportation } \\
\text { accident }\end{array}$ & release & 1 & 1 & - \\
\hline \multirow{3}{*}{$\begin{array}{l}\text { Holdup in process } \\
\text { equipment or ducts }\end{array}$} & breach of facility & - & 1 & 1 \\
\hline & fire & 1 & - & - \\
\hline & criticality & - & 11 & - \\
\hline $\begin{array}{l}\text { Contaminated } \\
\text { rooms or equipment }\end{array}$ & release & - & - & 1 \\
\hline $\begin{array}{l}\text { unnecessary } \\
\text { combustible } \\
\text { material }\end{array}$ & fire or explosions & 2 & 7 & 3 \\
\hline
\end{tabular}




\subsection{Reductions in Hazard Likelihood (HL) Factor}

Actions taken to reduce the risk from an identified deficiency may result in a reduction in the likelihood of a controlling event. This section provides guidance on evaluating the reduction for representative events.

The reduction in likelihood is very situation specific and should be based on knowledge of the materials, conditions, and the facility in question. The reduction in likelihood should be based on the change in conditions affecting the event that is the cause of the potential release. Suggested ranges for likelihood reductions are presented in Table 4.5 for common initiating events or conditions that may contribute an accident. 
Table 4.5. Suggested Ranges of Likelihood Reductions

\begin{tabular}{|c|c|c|c|c|c|}
\hline Event of Concern & Mitigation Action & Initial Likelihood & Final Likelihood & Reduction Range & Comments \\
\hline \multirow[t]{2}{*}{ package failure } & $\begin{array}{l}\text { repackage to safe } \\
\text { form }\end{array}$ & package failure rate & $\begin{array}{l}\text { repackaged failure } \\
\text { rate }\end{array}$ & $0.1-1 \mathrm{E}-6$ & $\begin{array}{l}\text { depends on level of } \\
\text { improvement in packaging }\end{array}$ \\
\hline & $\begin{array}{l}\text { move to facility with } \\
\text { better confinement }\end{array}$ & package failure rate & $\begin{array}{l}\text { same as initial } \\
\text { likelihood }\end{array}$ & 1.0 & no change in likelihood \\
\hline $\begin{array}{l}\text { facility failure } \\
\text { during seismic } \\
\text { event }\end{array}$ & strengthen facility & $\begin{array}{l}\text { frequency of } \\
\text { minimum earthquake } \\
\text { to cause failure }\end{array}$ & $\begin{array}{l}\text { frequency of design } \\
\text { earthquake }\end{array}$ & $0.1-1 \mathrm{E}-4$ & $\begin{array}{l}\text { depends on seismic } \\
\text { frequencies for the site }\end{array}$ \\
\hline human error & staff training & $\begin{array}{l}\text { likelihood of human } \\
\text { error for untrained } \\
\text { staff }\end{array}$ & $\begin{array}{l}\text { likelihood of human } \\
\text { error for trained staff }\end{array}$ & $0.5-0.01$ & $\begin{array}{l}\text { training is likely to reduce } \\
\text { the frequency of human error } \\
\text { events }\end{array}$ \\
\hline \multirow[t]{3}{*}{ facility fire } & $\begin{array}{l}\text { improve facility fire } \\
\text { suppression system }\end{array}$ & $\begin{array}{l}\text { facility fire frequency } \\
\text { without suppression } \\
\text { system }\end{array}$ & $\begin{array}{l}\text { facility fire frequency } \\
\text { with suppression } \\
\text { system }\end{array}$ & $0.1-1 \mathrm{E}-4$ & $\begin{array}{l}\text { improvement in fire } \\
\text { suppression systems will } \\
\text { reduce the likelihood of a } \\
\text { major fire }\end{array}$ \\
\hline & $\begin{array}{l}\text { remove/mitigate fire } \\
\text { initiation conditions }\end{array}$ & $\begin{array}{l}\text { fire likelihood under } \\
\text { initial conditions }\end{array}$ & $\begin{array}{l}\text { fire likelihood under } \\
\text { mitigated conditions }\end{array}$ & $0.01-1 \mathrm{E}-6$ & $\begin{array}{l}\text { improving conditions } \\
\text { reduces likelihood of a fire } \\
\text { starting }\end{array}$ \\
\hline & $\begin{array}{l}\text { remove combustible } \\
\text { material }\end{array}$ & $\begin{array}{l}\text { fire likelihood due to } \\
\text { combustible material }\end{array}$ & $\begin{array}{l}\text { fire likelihood without } \\
\text { combustible material }\end{array}$ & $0.1-1 \mathrm{E}-6$ & $\begin{array}{l}\text { removing combustible } \\
\text { materials reduces likelihood } \\
\text { of a fire of magnitude to } \\
\text { cause release }\end{array}$ \\
\hline container breach & $\begin{array}{l}\text { vitrify and store in } \\
\text { solid form }\end{array}$ & $\begin{array}{l}\text { frequency of initial } \\
\text { container breach }\end{array}$ & $\begin{array}{l}\text { frequency of new } \\
\text { container breach }\end{array}$ & $0.5-1 \mathrm{E}-4$ & $\begin{array}{l}\text { depends on container } \\
\text { modifications more than } \\
\text { physical form of material }\end{array}$ \\
\hline criticality & $\begin{array}{l}\text { reconfigure material } \\
\text { or add administrative } \\
\text { controls }\end{array}$ & $\begin{array}{l}\text { initial criticality } \\
\text { frequency }\end{array}$ & $\begin{array}{l}\text { criticality frequency } \\
\text { after reconfiguration } \\
\text { or controls }\end{array}$ & $0.1-1 \mathrm{E}-4$ & $\begin{array}{l}\text { reconfiguration to limit } \\
\text { material below critical mass } \\
\text { will reduce likelihood of } \\
\text { criticality }\end{array}$ \\
\hline
\end{tabular}




\subsection{Risk Measure (RM) Application Example}

An example is presented in this section for evaluation of the risk measure as a function of time. The example involves two of the plutonium vulnerabilities identified for the Savannah River site in the Plutonium Vulnerability Assessment Project. The two vulnerabilities represent material that has been stabilized and for which the vulnerability is considered to be closed. The vulnerabilities are described as follows (DOE 1995).

SR-B235-6 Pressure buildup of containers bearing Pu-238 materials due to decay may result in releases. The material has been vented and repackaged into a form suitable for interim storage (in EP-61 containers) in the HB-line facility. The material will be safely monitored and stored for eventual use in future NASA programs. Completion date was March 1995.

SR-FC-2 Plutonium solutions in F-Canyon are unsuitable for extended storage and represent a risk of criticality. The solutions have been converted to safe, storable plutonium metal through operation of the F-Canyon and the FBLine. Completion date was April 1996.

Note: although the example is based on actual vulnerabilities, the results of the example analysis should not be taken to reflect the actual changes in risk for the SRS site. To improve illustration of the risk assessment method, changes have been made to assessment parameters (i.e., likelihood values and release fractions) resulting in risk measures not representative of the actual situation at SRS.

The initial value of the risk measure is equal to the initial frequency of the event (when only one event is considered). The ending value is based on changes in parameter values resulting from actions taken to reduce the risk from the vulnerability. The parameter values for the two vulnerabilities are presented in Table 5.1 for initial conditions, and for the final state of the material. These parameter values are used to evaluate the relative hazard and the risk measure at the start and at the end of the remedial action for each vulnerability. The evaluation of relative hazard and risk measure for these vulnerabilities follows. Each vulnerability is first evaluated separately, then an analysis is done to demonstrate combination of two events into one analysis. For these analyses, the assumption is made that processing for both vulnerabilities starts at the same time (mid1994) and that material is stabilized at a uniform rate during each processing period.

Note that the frequency for vulnerability SR-FC-2 was defined as "high" in the vulnerability study, but has been changed to "extremely unlikely" (1E-5/yr) in the present analysis for illustrative purposes. 
Table 5.1 Parameter Values for Two SRS Vulnerabilities

\begin{tabular}{|c|c|c|c|c|c|}
\hline \multirow[b]{2}{*}{ Parameter } & \multirow[b]{2}{*}{ Time } & \multicolumn{2}{|c|}{ Vulnerability SR-B235-6 } & \multicolumn{2}{|c|}{ Vulnerability SR-FC-2 } \\
\hline & & Value & Comment & Value & Comment \\
\hline \multirow[t]{2}{*}{$\mathrm{Q}$} & Initial & $\begin{array}{c}5000 \mathrm{Ci} \\
{ }^{238} \mathrm{Pu}\end{array}$ & $\begin{array}{l}\text { Approximate content of } 1 \text { of } 15 \\
\text { containers involved in the } \\
\text { vulnerability }\end{array}$ & $1 \mathrm{E} 6 \mathrm{Ci}^{239} \mathrm{Pu}$ & $\begin{array}{l}\text { Approximate total amount of } \\
{ }^{239} \mathrm{Pu} \text { in } 15 \text { tanks }\end{array}$ \\
\hline & Final & $\begin{array}{l}{ }^{5000 \mathrm{Ci}} \\
{ }^{238} \mathrm{Pu}\end{array}$ & No change in material quantity & $1 \mathrm{E} 6 \mathrm{Ci}^{239} \mathrm{Pu}$ & No change in material quantity \\
\hline \multirow[t]{2}{*}{$\mathrm{HL}$} & Initial & 0.3 & $\begin{array}{l}\text { Based on assessment of } \\
\text { moderate likelihood by } \mathrm{Pu} \\
\text { vulnerability project for an event } \\
\text { involving any of the } 15 \\
\text { containers }\end{array}$ & $1 \mathrm{E}-5$ & $\begin{array}{l}\text { The vulnerability study set the } \\
\text { frequency to "high", but it has } \\
\text { been reset to " extremely } \\
\text { unlikely" for illustrative } \\
\text { purposes. }\end{array}$ \\
\hline & Final & 0.001 & $\begin{array}{l}\text { Venting and repackaging reduce } \\
\text { the likelihood of a release event } \\
\text { to unlikely }\end{array}$ & $1 \mathrm{E}-5$ & $\begin{array}{l}\text { No change in event frequency is } \\
\text { considered for this vulnerability, } \\
\text { for illustrative purposes. }\end{array}$ \\
\hline \multirow[t]{2}{*}{$\mathrm{RF}$} & Initial & $7 \mathrm{E}-5$ & $\begin{array}{l}\text { Based on pressure release from } \\
\text { container per Pu vulnerability } \\
\text { project methodology (Lai 1995) }\end{array}$ & $1 \mathrm{E}-7$ & $\begin{array}{l}\text { Based on spill event per } \mathrm{Pu} \\
\text { vulnerability project } \\
\text { methodology (Lai 1995) }\end{array}$ \\
\hline & Final & $1 \mathrm{E}-7$ & $\begin{array}{l}\text { Based on release caused by drop } \\
\text { of a container per } \mathrm{Pu} \\
\text { vulnerability project } \\
\text { methodology (Lai 1995) }\end{array}$ & $1 \mathrm{E}-7$ & $\begin{array}{l}\text { Based on container drop per } \mathrm{Pu} \\
\text { vulnerability project } \\
\text { methodology (Lai 1995) }\end{array}$ \\
\hline \multirow[t]{2}{*}{ HM } & Initial & $1 \mathrm{E} 4$ & $\begin{array}{l}\text { Category IV for airborne release } \\
\text { of }{ }^{238} \mathrm{Pu}(\text { Table } 2.1)\end{array}$ & $1 \mathrm{E} 4$ & $\begin{array}{l}\text { Category IV for airborne release } \\
\text { of }{ }^{239} \mathrm{Pu} \text { (Table } 2.1 \text { ) }\end{array}$ \\
\hline & Final & $1 \mathrm{E} 4$ & $\begin{array}{l}\text { No change in composition or } \\
\text { pathway }\end{array}$ & $1 \mathrm{E} 4$ & $\begin{array}{l}\text { No change in composition or } \\
\text { pathway }\end{array}$ \\
\hline \multirow[t]{2}{*}{$\mathrm{HC}$} & Initial & 1 & Initial value by definition & 1 & Initial value by definition \\
\hline & Final & 1 & $\begin{array}{l}\text { No change in physical state } \\
\text { (solid) }\end{array}$ & $1 \mathrm{E}-5$ & $\begin{array}{l}\text { Based on solidification per } \\
\text { Table } 2.14 \text { for SRS setting A-M }\end{array}$ \\
\hline \multirow[t]{2}{*}{ RR } & Initial & 1.0 & Initial value by definition & 1.0 & Initial value by definition \\
\hline & Final & $\begin{array}{c}6.7 \mathrm{E}-5 \\
(\mathrm{March} \\
1995)\end{array}$ & $\begin{array}{l}\text { Gradual reduction over } \\
\text { processing period from mid- } \\
1994 \text { to March } 1995\end{array}$ & $\begin{array}{c}\text { 3E-10 } \\
\text { (April 1996) }\end{array}$ & $\begin{array}{l}\text { Gradual reduction over } \\
\text { processing period from mid- } \\
1994 \text { to April } 1996\end{array}$ \\
\hline
\end{tabular}

\section{Evaluations for Vulnerability SR-B235-6}

For vulnerability SR-B235-6, the denominator of the relative hazard and risk measure equations is:

Denominator $(\mathrm{RH}$ and $\mathrm{RM})=5000 \times 7 \mathrm{E}-5 \times 1 \mathrm{E} 4 \times 1=3,500$.

At time zero, the numerator of the relative hazard equation is equal to the denominator and the $\mathrm{RH}$ value is 1.0. The material is completely processed and stabilized in 9 months. At that time the numerator of the relative hazard equation is:

Numerator at 9 months $(\mathrm{RH})=5000 \times 1 \mathrm{E}-7 \times 1 \mathrm{E} 4 \times 1=5$

The relative hazard factor at 9 months is then $5 / 3,500=0.0014$

The initial RM is equal to the initial frequency which is 0.3 .

At 9 months the RM numerator is $5000 \times 0.001 \times 1 \mathrm{E}-7 \times 1 \mathrm{E} 4 \times 1=5 \mathrm{E}-3$ 
At 9 months the risk measure is $5 \mathrm{E}-3 / 3,500=1.4 \mathrm{E}-6$

\section{Evaluations for Vulnerability SR-FC-2}

For vulnerability SR-FC-2 the denominator of the relative hazard and risk measure equations is:

Denominator $(\mathrm{RH}$ and RM) $=1 \mathrm{E} 6 \times 1 \mathrm{E}-7 \times 1 \mathrm{E} 4 \times 1=1 \mathrm{E} 3$.

At time zero, the numerator of the relative hazard equation is equal to the denominator and the RH value is 1.0. The material is completely processed and stabilized in 22 months. At that time the numerator of the relative hazard equation is:

Numerator at 22 months $(\mathrm{RH})=1 \mathrm{E} 6 \times 1 \mathrm{E}-7 \times 1 \mathrm{E} 4 \times 1 \mathrm{E}-5=1 \mathrm{E}-2$.

The relative hazard factor at 22 months is then $1 \mathrm{E}-2 / 1 \mathrm{E} 3=1 \mathrm{E}-5$

The initial RM is equal to the initial frequency which is $1 \mathrm{E}-7$.

At 22 months the RM numerator is $1 \mathrm{E} 6 \times 1 \mathrm{E}-5 \times 1 \mathrm{E}-7 \times 1 \mathrm{E} 4 \times 1 \mathrm{E}-5=1 \mathrm{E}-7$

At 22 months the $\mathrm{RM}$ is $1 \mathrm{E}-7 / 1 \mathrm{E} 3=1 \mathrm{E}-10$

\section{Evaluations for Combining the Two Vulnerabilities}

The net reduction in relative hazard and risk can be evaluated for the two vulnerabilities as a group by applying the summation over exposure scenarios (e.g., vulnerabilities). The denominator in the RM evaluation is the sum of the initial values for each vulnerability:

Denominator for RM combined $=3,500+1,000=4,500$

The numerator initial value is the sum of the initial values for each vulnerability:

Initial RM numerator vulnerability $1=5000 \times 0.3 \times 7 \mathrm{E}-5 \times 1 \mathrm{E} 4 \times 1=1,050$

Initial RM numerator vulnerability $2=1 \mathrm{E} 6 \times 1 \mathrm{E}-7 \times 1 \mathrm{E}-5 \times 1 \mathrm{E} 4 \times 1=0.01$

Initial RM numerator combined $=1,050+0.01=1,050$

The initial $\mathrm{RM}$ is $1,050 / 4,500=0.233$

At the end of all processing ( 22 months) both vulnerabilities are in their final state and the RM is as follows using final numerator values from above: 
$\mathrm{RM}$ at 22 months $=(5 \mathrm{E}-3+1 \mathrm{E}-7) / 4500=1.1 \mathrm{E}-6$

At intermediate times when one or both vulnerabilities are only partially completed, it is necessary to consider the fraction of material that has been process (e.g. stabilized). At 9 months the first vulnerability is just completed, but the second vulnerability is still being processed. For processing at a uniform rate, the second vulnerability would be 9/22 complete: $9 / 22=0.409$ stabilized and 0.591 still unstabilized. The RM is evaluated as the sum of three components, vulnerability 1 completed, vulnerability 2 stabilized (0.409), and vulnerability 2 unstabilized (0.591). Using numerator values defined above, and the stabilization fractions, the following $\mathrm{RH}$ and $\mathrm{RM}$ values are obtained.

$\mathrm{RH}$ at 9 months $=(5.0+0.409 \times 1 \mathrm{E}-2+0.591 \times 1 \mathrm{E} 3) / 4,500=5.96 \mathrm{E} 2 / 4,500=0.132$

$\mathrm{RM}$ at 9 months $=(5 \mathrm{E}-3+0.409 \times 1 \mathrm{E}-7+0.591 \times 0.01) / 4,500=1.09 \mathrm{E}-2 / 4,500=$ 2.4E-6

The RH and RM values for three analyses (i.e., vulnerability 1, vulnerability 2 , and the combined case) are plotted in following figures.

SR-B235-6 Scenario

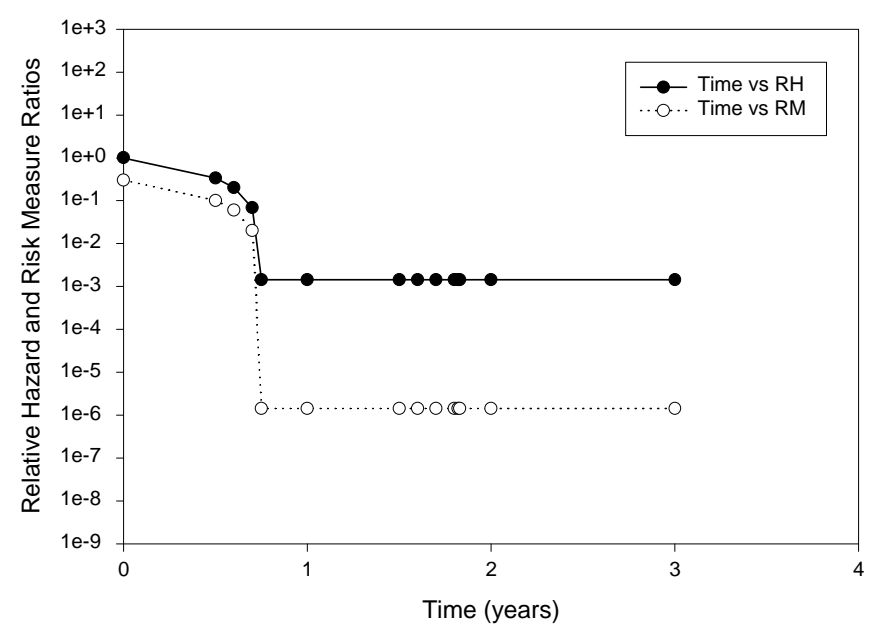


SR-FC-2 Scenario

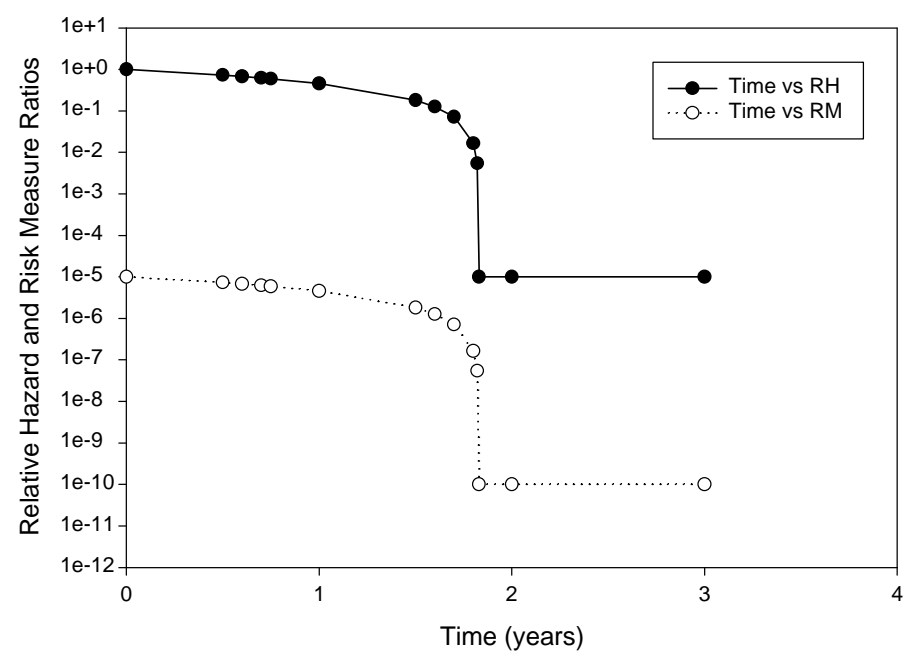

Sumation Scenario

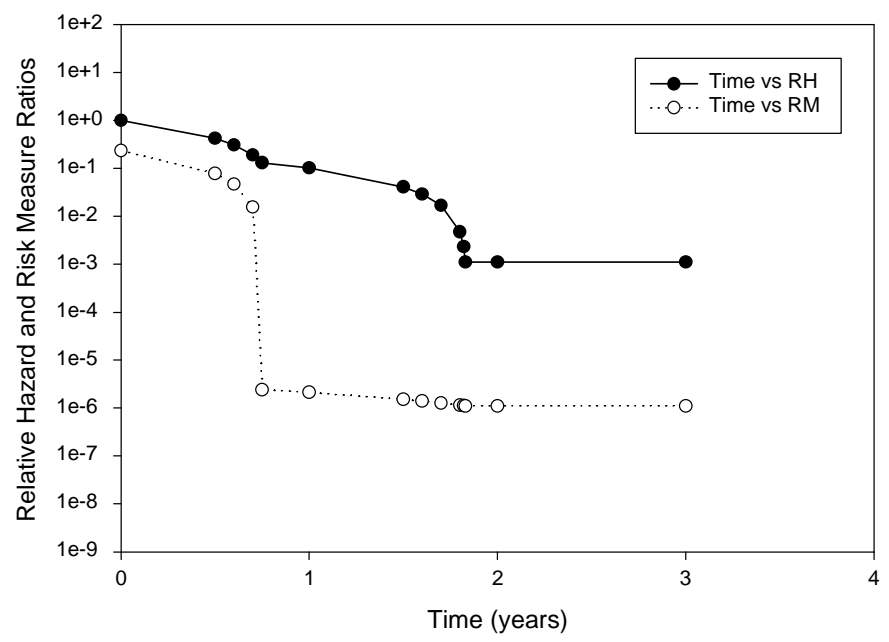




\section{Plot Table for Example Graphs}

\begin{tabular}{|c|c|c|c|c|c|c|c|c|c|c|}
\hline time $(y r)$ & Vul No & Q1 & $\mathrm{RF} 1$ & $\mathrm{HC} 1$ & HM1 & HL & $\mathrm{RHN}$ & $\mathrm{RMN}$ & $\mathrm{RH}$ & $\mathrm{RM}$ \\
\hline 0 & SR-B235-6 & 5000 & $7.00 \mathrm{E}-05$ & 1 & $1.00 \mathrm{E}+04$ & 0.3 & $3.50 \mathrm{E}+03$ & $1.05 E+03$ & $1.00 \mathrm{E}+00$ & $3.00 \mathrm{E}-01$ \\
\hline 0.5 & & 5000 & $7.00 \mathrm{E}-05$ & 1 & $1.00 E+04$ & 0.3 & $1.17 \mathrm{E}+03$ & $3.50 \mathrm{E}+02$ & 3.34E-01 & $1.00 \mathrm{E}-01$ \\
\hline 0.6 & & 5000 & $7.00 \mathrm{E}-05$ & 1 & $1.00 \mathrm{E}+04$ & 0.3 & $7.04 \mathrm{E}+02$ & $2.10 \mathrm{E}+02$ & $2.01 \mathrm{E}-01$ & $6.00 \mathrm{E}-02$ \\
\hline 0.7 & & 5000 & $7.00 \mathrm{E}-05$ & 1 & $1.00 \mathrm{E}+04$ & 0.3 & $2.38 \mathrm{E}+02$ & $7.00 \mathrm{E}+01$ & $6.80 \mathrm{E}-02$ & 2.00E-02 \\
\hline 0.75 & & 5000 & $1.00 \mathrm{E}-07$ & 1 & $1.00 \mathrm{E}+04$ & 0.001 & $5.00 \mathrm{E}+00$ & $5.00 \mathrm{E}-03$ & 1.43E-03 & 1.43E-06 \\
\hline 1 & & 5000 & $1.00 \mathrm{E}-07$ & 1 & $1.00 \mathrm{E}+04$ & 0.001 & $5.00 \mathrm{E}+00$ & $5.00 \mathrm{E}-03$ & 1.43E-03 & 1.43E-06 \\
\hline 1.5 & & 5000 & $1.00 \mathrm{E}-07$ & 1 & $1.00 \mathrm{E}+04$ & 0.001 & $5.00 \mathrm{E}+00$ & $5.00 \mathrm{E}-03$ & 1.43E-03 & 1.43E-06 \\
\hline 1.6 & & 5000 & $1.00 \mathrm{E}-07$ & 1 & $1.00 \mathrm{E}+04$ & 0.001 & $5.00 \mathrm{E}+00$ & $5.00 \mathrm{E}-03$ & 1.43E-03 & 1.43E-06 \\
\hline 1.7 & & 5000 & $1.00 \mathrm{E}-07$ & 1 & $1.00 \mathrm{E}+04$ & 0.001 & $5.00 \mathrm{E}+00$ & $5.00 \mathrm{E}-03$ & 1.43E-03 & 1.43E-06 \\
\hline 1.8 & & 5000 & $1.00 \mathrm{E}-07$ & 1 & $1.00 \mathrm{E}+04$ & 0.001 & $5.00 \mathrm{E}+00$ & $5.00 \mathrm{E}-03$ & 1.43E-03 & 1.43E-06 \\
\hline 1.82 & & 5000 & $1.00 \mathrm{E}-07$ & 1 & $1.00 \mathrm{E}+04$ & 0.001 & $5.00 \mathrm{E}+00$ & $5.00 \mathrm{E}-03$ & 1.43E-03 & 1.43E-06 \\
\hline 1.83 & & 5000 & $1.00 \mathrm{E}-07$ & 1 & $1.00 \mathrm{E}+04$ & 0.001 & $5.00 \mathrm{E}+00$ & $5.00 \mathrm{E}-03$ & 1.43E-03 & 1.43E-06 \\
\hline 2 & & 5000 & $1.00 \mathrm{E}-07$ & 1 & $1.00 \mathrm{E}+04$ & 0.001 & $5.00 \mathrm{E}+00$ & $5.00 \mathrm{E}-03$ & $1.43 E-03$ & $1.43 E-06$ \\
\hline 3 & & 5000 & $1.00 \mathrm{E}-07$ & 1 & $1.00 \mathrm{E}+04$ & 0.001 & $5.00 \mathrm{E}+00$ & $5.00 \mathrm{E}-03$ & $1.43 \mathrm{E}-03$ & $1.43 \mathrm{E}-06$ \\
\hline time $(y r)$ & Vul No & Q1 & $\mathrm{RF} 1$ & $\mathrm{HC} 1$ & HM1 & $\mathrm{HL}$ & $\mathrm{RHN}$ & $\mathrm{RMN}$ & $\mathrm{RH}$ & $\mathrm{RM}$ \\
\hline 0 & SR-FC-2 & $1.00 \mathrm{E}+06$ & $1.00 \mathrm{E}-07$ & 1 & $1.00 E+04$ & $1.00 \mathrm{E}-05$ & $1.00 \mathrm{E}+03$ & $1.00 \mathrm{E}-02$ & $1.00 E+00$ & $1.00 \mathrm{E}-05$ \\
\hline 0.5 & & $1.00 \mathrm{E}+06$ & $1.00 \mathrm{E}-07$ & 1 & $1.00 \mathrm{E}+04$ & $1.00 \mathrm{E}-05$ & $7.27 \mathrm{E}+02$ & $7.27 \mathrm{E}-03$ & 7.27E-01 & $7.27 \mathrm{E}-06$ \\
\hline 0.6 & & $1.00 \mathrm{E}+06$ & $1.00 \mathrm{E}-07$ & 1 & $1.00 \mathrm{E}+04$ & $1.00 \mathrm{E}-05$ & $6.72 \mathrm{E}+02$ & $6.72 \mathrm{E}-03$ & $6.72 \mathrm{E}-01$ & $6.72 \mathrm{E}-06$ \\
\hline 0.7 & & $1.00 \mathrm{E}+06$ & $1.00 \mathrm{E}-07$ & 1 & $1.00 \mathrm{E}+04$ & $1.00 \mathrm{E}-05$ & $6.17 \mathrm{E}+02$ & $6.17 \mathrm{E}-03$ & $6.17 \mathrm{E}-01$ & $6.17 \mathrm{E}-06$ \\
\hline 0.75 & & $1.00 \mathrm{E}+06$ & $1.00 \mathrm{E}-07$ & 1 & $1.00 \mathrm{E}+04$ & $1.00 \mathrm{E}-05$ & $5.90 \mathrm{E}+02$ & $5.90 \mathrm{E}-03$ & $5.90 \mathrm{E}-01$ & $5.90 \mathrm{E}-06$ \\
\hline 1 & & $1.00 \mathrm{E}+06$ & $1.00 \mathrm{E}-07$ & 1 & $1.00 \mathrm{E}+04$ & $1.00 \mathrm{E}-05$ & $4.54 \mathrm{E}+02$ & 4.54E-03 & 4.54E-01 & $4.54 \mathrm{E}-06$ \\
\hline 1.5 & & $1.00 \mathrm{E}+06$ & $1.00 \mathrm{E}-07$ & 1 & $1.00 \mathrm{E}+04$ & $1.00 \mathrm{E}-05$ & $1.80 \mathrm{E}+02$ & $1.80 \mathrm{E}-03$ & $1.80 \mathrm{E}-01$ & $1.80 \mathrm{E}-06$ \\
\hline 1.6 & & $1.00 \mathrm{E}+06$ & $1.00 \mathrm{E}-07$ & 1 & $1.00 \mathrm{E}+04$ & $1.00 \mathrm{E}-05$ & $1.26 \mathrm{E}+02$ & $1.26 \mathrm{E}-03$ & 1.26E-01 & 1.26E-06 \\
\hline 1.7 & & $1.00 \mathrm{E}+06$ & $1.00 \mathrm{E}-07$ & 1 & $1.00 \mathrm{E}+04$ & $1.00 \mathrm{E}-05$ & $7.10 \mathrm{E}+01$ & $7.10 \mathrm{E}-04$ & $7.10 \mathrm{E}-02$ & $7.10 \mathrm{E}-07$ \\
\hline 1.8 & & $1.00 \mathrm{E}+06$ & $1.00 \mathrm{E}-07$ & 1 & $1.00 \mathrm{E}+04$ & $1.00 \mathrm{E}-05$ & $1.64 \mathrm{E}+01$ & $1.64 \mathrm{E}-04$ & $1.64 \mathrm{E}-02$ & $1.64 \mathrm{E}-07$ \\
\hline 1.82 & & $1.00 \mathrm{E}+06$ & $1.00 \mathrm{E}-07$ & 1 & $1.00 \mathrm{E}+04$ & $1.00 \mathrm{E}-05$ & $5.47 \mathrm{E}+00$ & $5.47 \mathrm{E}-05$ & $5.47 \mathrm{E}-03$ & $5.47 \mathrm{E}-08$ \\
\hline 1.83 & & $1.00 \mathrm{E}+06$ & $1.00 \mathrm{E}-07$ & $1.00 \mathrm{E}-05$ & $1.00 \mathrm{E}+04$ & $1.00 \mathrm{E}-05$ & $1.00 \mathrm{E}-02$ & $1.00 \mathrm{E}-07$ & $1.00 \mathrm{E}-05$ & $1.00 \mathrm{E}-10$ \\
\hline 2 & & $1.00 \mathrm{E}+06$ & $1.00 \mathrm{E}-07$ & $1.00 \mathrm{E}-05$ & $1.00 \mathrm{E}+04$ & $1.00 \mathrm{E}-05$ & $1.00 \mathrm{E}-02$ & $1.00 \mathrm{E}-07$ & $1.00 \mathrm{E}-05$ & $1.00 \mathrm{E}-10$ \\
\hline 3 & & $1.00 \mathrm{E}+06$ & $1.00 \mathrm{E}-07$ & $1.00 \mathrm{E}-05$ & $1.00 \mathrm{E}+04$ & $1.00 \mathrm{E}-05$ & $1.00 \mathrm{E}-02$ & $1.00 \mathrm{E}-07$ & $1.00 \mathrm{E}-05$ & $1.00 \mathrm{E}-10$ \\
\hline Combined & Analysis & & & & & & $\mathrm{RH}$ & $\mathrm{RM}$ & & \\
\hline 0 & Both & & & & & & $1.00 \mathrm{E}+00$ & 2.33E-01 & & \\
\hline 0.5 & & & & & & & 4.22E-01 & $7.78 \mathrm{E}-02$ & & \\
\hline 0.6 & & & & & & & $3.06 \mathrm{E}-01$ & $4.67 \mathrm{E}-02$ & & \\
\hline 0.7 & & & & & & & $1.90 \mathrm{E}-01$ & 1.56E-02 & & \\
\hline 0.75 & & & & & & & $1.32 \mathrm{E}-01$ & $2.42 \mathrm{E}-06$ & & \\
\hline 1 & & & & & & & $1.02 \mathrm{E}-01$ & 2.12E-06 & & \\
\hline 1.5 & & & & & & & $4.12 \mathrm{E}-02$ & $1.51 \mathrm{E}-06$ & & \\
\hline 1.6 & & & & & & & $2.90 \mathrm{E}-02$ & 1.39E-06 & & \\
\hline 1.7 & & & & & & & $1.69 \mathrm{E}-02$ & $1.27 \mathrm{E}-06$ & & \\
\hline 1.8 & & & & & & & $4.76 \mathrm{E}-03$ & $1.15 \mathrm{E}-06$ & & \\
\hline 1.82 & & & & & & & $2.33 \mathrm{E}-03$ & $1.12 \mathrm{E}-06$ & & \\
\hline 1.83 & & & & & & & $1.11 \mathrm{E}-03$ & $1.11 \mathrm{E}-06$ & & \\
\hline 2 & & & & & & & $1.11 \mathrm{E}-03$ & $1.11 \mathrm{E}-06$ & & \\
\hline 3 & & & & & & & $1.11 \mathrm{E}-03$ & $1.11 \mathrm{E}-06$ & & \\
\hline
\end{tabular}




\subsection{Application Data for Risk Profile Update}

The intent of the methodology is for use in generating relative hazard and risk measure graphs for the CRE risk profiles. The purpose of these graphs is to graphically display the hazards that must be managed over time in relation to the management of an acceptable level of risk that must be maintained.

As a result of the Savannah River Site (SRS) Citizen Advisory Board's (CAB) interest and recommended improvements to their FY-99 SRS Risk Profile, the methodology was developed in communication and cooperation with the SRS CAB. To make sure the methodology is applicable for updating the SRS Risk Profile, a series of SRS data sources have been identified and reviewed for adequacy of data for the establishment of necessary parameter inputs to the models utilized by the methodology. The broader DOE picture has also been kept in mind, in that the methodology will also need to be applicable to upgrading the CRE risk profiles for other major sites within the DOE system. Thus, the SRS is serving as a prototype site for developing the methodology to upgrade the risk profiles for the major DOE sites.

The SRS data sources investigated include:

- The full series of Safety Analysis Reports (SARs) for the various facilities and operations at the SRS

- Interim safety basis documents that fill in for operations for which up-to-date SARs are not available or no longer applicable

- Site wide or program specific Environmental Impact Statements

- The Path to Closure Document and associated databases (i.e., IDMS and AVS databases)

- CERCLA and RCRA program documents and permits

Based on the review conducted, it is believed that sufficient data are available to apply the methodology. While there will be specific data investigations that will need to be established when applying the methodology to upgrading the SRS sites full compliment of risk types, it is believed that the following investigative process will produce the necessary data with relative ease:

- Review the series of SARs available for each waste type (e.g., HLW, LLW, etc.) to establish a list of significant facilities/operations that have applicable SARs

- Using SAR based Hazard Evaluation Tables, which display the events, initiators, frequency probabilities, and risk rankings, determine the controlling scenario(s) (the frequency and risk rank combination provides the necessary analysis information to select the controlling events)

- Establish the HL factors directly from the frequency probabilities (in cases where SARs are not available, a process similar to the one used for the SAR will be applied to CERCLA, RCRA, etc. scenario information to establish the HL factor)

- The $\mathrm{Q}$ factor data will be taken directly from the source term data provided for the SAR, etc. analyses 
- The HM factors can be derived by using the source term data and the look-up tables provided with the methodology

- The RF factors can be determined directly from the source term and scenario description data. For the analyses provided in SARs, CERCLA, RCRA, etc. analyses, the source term will either be provided as a releasable quantity $(\mathrm{Q})$, where the RF would simply be equal to 1; or the source term data will be total amounts and a release fraction will be identified to determine how much of the total quantity is releasable through the scenario being analyzed

- The HC factors can be determined using the Path to Closure document action descriptions and the look-up tables provided in the methodology

- Once the controlling facility/operation scenarios and associated data are establish from the SARs, it will be necessary to review these identified facility/operation facility scenarios with the waste volume list generated for the risk profile tables (extracted from the Path to Closure document) to make sure all the inventory groups are adequately represented by the controlling scenarios identified. For those waste volumes not represented by facilities/operations having SARs, the CERCLA, RCRA, etc. documents will need to be examined to establish scenario(s) that do represent them.

In updating the risk profiles, it will be important to consult with appropriate site representatives to ensure that the controlling scenarios do adequately represent the hazard and risk management story that needs to be told for the site. In selecting the controlling scenarios, it will be important to think life cycle of the waste material being analyzed. In doing so a full compliment of controlling scenarios can be selected that will represent the controlling hazards as conditions change as a result of clean up action implementation over the full life cycle of the waste type.

\subsection{Summary}

The Center for Risk Excellence (CRE) was created and charged as a technical, fieldbased partner to the Office of Science and Risk Policy (EM-52). One of the initial charges to the CRE is to assist the sites in the development of "site risk profiles." Graphic illustrations were needed in these profiles to provide the reader with a high-level mental picture to associate with all the qualitative risk management information presented in the risk profile. The methodology presented in this document was developed to provide a means of calculating the $\mathrm{RH}$ ratios and $\mathrm{RM}$ values to use in developing these graphic illustrations.

The RH equation, as presented in this methodology, is primarily a collection of key factors that are relevant to understanding the hazards and risks associated with projected risk management activities. The $\mathrm{RH}$ equation has the potential for much broader application, than was used in generating the risk profiles. For example, it can be used to compare one risk management activity with another, instead of just comparing it to a fixed baseline like was done for the risk profiles. If the appropriate source term data are available, it could be used in its non-ratio form to estimate absolute values of the associated hazards. These estimated values of hazard could then be examined to help 
understand which risk management activities are addressing the higher hazard conditions at a site. Graphics could be generated from these absolute hazard values to pictorially show and compare these high hazard conditions. If the RH equation is used in this manner, care must be taken to specifically define and qualify (e.g., identify which factors were considered and which ones tended to drive the hazard estimation) the estimated absolute hazard values.

The risk measure, RM, was developed to extend the RH analysis to a measure of the potential risk from the hazardous material. The RM value includes the likelihood of a release to the environment based on the facility conditions and material packaging configuration. As the material is processed for safety improvements or waste treatment the likelihood of the release event will usually be reduced and the risk measure will also be reduced. The RM and RH values are both normalized to the same quantity (i.e., denominator of the RH equation) so the parameter can be plotted on the same graph.

\subsection{References}

40 CFR 302, U.S. Environmental Protection Agency, Designation of Hazardous Substances. 1989. Code of Federal Regulations.

Buck, J.W., L.M. Bagaasen, M.P. Bergeron, G.P. Streile, L.H. Staven, K.J. Castleton, G.M. Gelston, D.L. Strenge, K.M. Krupka, R.J. Serne, and T.A. Ikenberry. 1997. Analysis of the Long-Term Impact of TRU Waste Remaining at Generator Sites for No Action Alternative 2." PNL-11251, Pacific Northwest National Laboratory, Richland WA.

DOE. 1994. Plutonium Working Group Report on Environmental, Safety and Health Vulnerabilities Associated with the Department's Plutonium Storage. DOE/EH-0415, Volume 1: Summary and Attachment B (Vulnerability Summary Table). U.S. Department of Energy, Washington, DC.

DOE. 1995. Plutonium Vulnerability Management Plan. DOE/EM-0199. U.S. Department of Energy, Washington, DC.

DOE. 1996. Highly Enriched Uranium Working Group Report on Environmental, Safety and Health Vulnerabilities Associated with the Department's Storage of Highly Enriched Uranium. DOE/EH-0525, Attachment C Vulnerability Summary Table. U.S. Department of Energy, Washington, DC.

DOE. 1998a. Richland Operations Office: Risk Prospectus - Hanford Site. U.S. Department of Energy, Center for Risk Excellence, Argonne, IL.

DOE. 1998b. Nevada Operations Office: Human Health and Safety Risk SummaryNevada Test Site and Off-Site Test Areas. U.S. Department of Energy, Center for Risk Excellence, Argonne, IL. 
DOE. 1998c. Rocky Flats Field Office: Risk Summary - Rocky Flats Environmental Technology Site. U.S. Department of Energy, Center for Risk Excellence, Argonne, IL.

DOE. 1998d. Savannah River Operations Office: Risk Summary - Savannah River Site. U.S. Department of Energy, Center for Risk Excellence, Argonne, IL.

DOE. 1998e. Albuquerque Operations Office: Risk Summary - Pantex Plant, Sandia National Laboratories, and Los Alamos National Laboratory. U.S. Department of Energy, Center for Risk Excellence, Argonne, IL.

EPA. 1982. Uncontrolled Hazardous Waste Site Ranking System, Appendix A. Subpart H of the National Oil and Hazardous Substance Contingency Plan. U.S. Environmental Protection Agency, Federal Register 31219-31243 (July 16, 1982).

Hawley, K.A. and B.A. Napier. 1985. A Ranking System for Mixed Radioactive and Hazardous Waste Sites in U.S. DOE. Proceedings of the Fifth DOE Environmental Protection Information Meeting. CONF-841187, Volume 1. Proceedings of a conference held in Albuquerque, New Mexico, November 6-8, 1984. U.S. Department of Energy, Washington, D.C.

Hawley, K.A., R.A. Peloquin, and R.D. Stenner. 1986. Modified Hazard Ranking System for Sites with Mixed Radioactive and Hazardous Wastes - User Manual. PNL-5841. Pacific Northwest Laboratory, Richland, WA.

Holdren, G.R., C.S. Glance, L.K. Berg, K. Kelinger, C.J. Fosmire, S.M. Goodwin, J.R. Rustad, R. Schalla, and J.A. Schramke. 1995. Environmental Settings for Selected U.S. Department of Energy Installations - Support Information for the Programmatic Environmental Impact Statement and the Baseline Management Report." PNNL-10550, Pacific Northwest National Laboratory, Richland, WA.

ICRP. 1959. Report of Committee II on Permissible Dose for Internal Radiation. International Commission on Radiological Protection, Publication 2, Pergamon Press, New York, NY.

ICRP. 1979. Limits for Intakes of Radionuclides by Workers. International Commission on Radiological Protection, Publication 30, Pergamon Press, New York, NY.

Lai, C. K. 1995. Plutonium ES\&H Vulnerability Assessment Vulnerability Evaluation Process. Presented at Environment, Safety \& Health Conference, Denver, CO. November 13-17, 1995. U.S. Department of Energy, Washington, DC.

Napier, B.A., R.A. Peloquin, D.L. Strenge, and J.V. Ramsdell. 1988a. Conceptual Representation. Volume 1 of GENII - The Hanford Environmental Radiation Dosimetry Software System. PNL-6584, Wolume 1, Pacific Northwest Laboratory, Richland, WA. 
Napier, B.A., R.A. Peloquin, D.L. Strenge, and J.V. Ramsdell. 1988b. User's Manual. Volume 2 of GENII - The Hanford Environmental Radiation Dosimetry Software System. PNL-6584, Volume 2, Pacific Northwest Laboratory, Richland, WA.

Napier, B.A., R.A. Peloquin, D.L. Strenge, and J.V. Ramsdell. 1988c. Code Maintenance Manual. Volume 3 of GENII -The Hanford Environmental Radiation Dosimetry Software System. PNL-6584, Volume 3, Pacific Northwest Laboratory, Richland, WA.

Serne, R.J. and M.I. Wood. 1990. Hanford Waste-Form Release and Sediment Interaction. PNL-7297. Pacific Northwest Laboratory, Richland, WA.

Strenge, D.L. and S.R. Peterson. 1989 Chemical Data Base for the Multimedia Environmental Pollutant Assessment System (MEPAS), Version 1. PNL-7145. Pacific Northwest Laboratory, Richland, WA.

Stenner, R.D., R.A. Peloquin, and K.A. Hawley. 1986. Modified Hazard Ranking System/Hazard Ranking System for Sites with Mixed Radioactive and Hazardous Wastes - Software Documentation. PNL-6066. Pacific Northwest Laboratory, Richland, WA.

Warren, B.R. and D.L. Strenge. 1994. Multimedia-Modeling Environmental Database and Editor (MMEDE): User Manual." PNNL-11562. Pacific Northwest National Laboratory, Richland,. WA. 